\title{
Petrological and geochemical characteristics of Palaeogene low-rank coal on the Faroe Islands: Restricted effects of alteration by basaltic lava flows
}

\author{
Simona Kuboušková a , Lukáš Krmíček ${ }^{\mathrm{a}, \mathrm{b}, \mathrm{c}, *}$, Pavel Coufalík ${ }^{\mathrm{d}, \mathrm{e}}$, Richard Pokorný ${ }^{\mathrm{f}}$ \\ a Department of Geological Sciences, Faculty of Science, Masaryk University, Kotlářská 2, CZ-611 37 Brno, Czech Republic \\ b Institute of Geology, The Czech Academy of Sciences, v.vi.., Rozvojová 269, CZ-165 02 Prague 6, Czech Republic \\ c Brno University of Technology, Faculty of Civil Engineering, AdMaS Centre, Veveři 95, CZ-602 00 Brno, Czech Republic \\ d Department of Chemistry, Faculty of Science, Masaryk University, Kotlářská 2, CZ-611 37 Brno, Czech Republic \\ e Institute of Analytical Chemistry, The Czech Academy of Sciences, v.v.i., Veveři 97, CZ-602 00 Brno, Czech Republic \\ ${ }^{\mathrm{f}}$ Faculty of Environment, Jan Evangelista Purkyně University, Králova Výšina 3132/7, CZ-400 96 Ústí nad Labem, Czech Republic
}

\section{A R T I C L E I N F O}

\section{Article history:}

Received 9 February 2016

Received in revised form 8 August 2016

Accepted 9 August 2016

Available online 10 August 2016

\section{Keywords:}

Faroe Islands

Coal composition

Alteration

Depositional environment

\begin{abstract}
A B S T R A C T
The first combined petrographic and geochemical investigation of coal from the Faroe Islands was performed as a case study to understand thermal effects from basaltic lava flows on immature coal. The samples were divided into two distinct groups: "normal" coal (xylite and detroxylite) and "altered organic matter" (charcoal and organic particles dispersed in samples rich in altered clastic mineral components or enriched via hydrothermal fluids). The "normal" coal consists primarily of huminite-group material dominated by ulminite. The proportions of material from inertinite and liptinite groups vary from sample to sample. The studied macerals are anisotropic with no observed reaction rims or vacuoles. According to the mean ulminite reflectance in combination with ultimate and proximate analyses, the coal reached the lignite and subbituminous stages. The maceral compositions together with coal palynology indicate a predominance of gelified wood-derived tissues and demonstrate that the coal evolved in wet forest swamps under limno-telmatic to telmatic conditions.

Alteration effects on immature coals from overlying basalt flows were relatively limited. Due to relatively rapid heat loss from the basaltic lava, as verified by the presence of volcanic glass (tachylyte), its imposed thermal effects resulted only in development of a thin "anthracite-like" crust on samples with no elevated coal rank. Associated hydrothermal fluids induced coal hydrofracturing with subsequent mineral precipitation and decomposition of the ambient feldspar-rich volcaniclastic sediments. Altered organic matter is enriched in $\mathrm{SiO}_{2}, \mathrm{Al}_{2} \mathrm{O}_{3}$ and $\mathrm{FeO}_{\text {tot, }}$ as well as in trace elements such as $\mathrm{Ni}$ and $\mathrm{Cr}$. In contrast, these samples are depleted in $\mathrm{Hg}(<10 \mathrm{ppb})$.
\end{abstract}

(c) 2016 Elsevier B.V. All rights reserved.

\section{Introduction}

The Faroe Islands $\left(1400 \mathrm{~km}^{2} ; 4^{\circ} \mathrm{S}\right.$ of the Arctic Circle) belong geologically to the North Atlantic Igneous Province (Saunders et al., 1997). Massive basalt lava flows of Palaeocene age (Storey et al., 2007) are interbedded with sedimentary layers containing thin coal lenses and seams. Continental interlava volcaniclastic sediments on the Faroe Islands provide only limited palaeontological evidence (plant remains, rare trace fossils) and their depositional environment has been highly debated (Pokorný et al., 2015 and references therein).

Coal has been a key fuel for the Faroe Islands, particularly in the past, due to their isolated geographical position and the limited import of fossil fuels. Because of its importance the coal was locally named "black gold" and has been mined in many adits since the 18th century to

\footnotetext{
* Corresponding author at: Institute of Geology, The Czech Academy of Sciences, v.v.i., Rozvojová 269, CZ-165 02 Prague 6, Czech Republic.

E-mail address: 1.krmicek@gmail.com (L. Krmíček).
}

ensure energy self-sufficiency. Coal productivity in 1930 was approximately 5000 tons/year. Since the beginning of the 21 st century, production has decreased to 100 tons/year (Øster-Mortensen, 2002). For this reason, only one coal mine has been in operation since 2008 .

The coal deposits are mentioned peripherally in several publications within basic geological descriptions of the Faroe Islands (e.g., Ellis et al., 2002; Laier et al., 1997; Lund, 1989; Parra et al., 1987; Passey, 2014; Rasmussen and Noe-Nygaard, 1969, 1970; Stokes, 1874). Nevertheless, they have not yet been systematically studied in terms of quality.

The chemical composition of coal varies considerably on the global scale (Mukherjee et al., 2008). The differences involve major element compositions (e.g., the commonly observed sulphur content) and trace element contents. The increasing environmental burden associated with the burning of fossil fuels places demands on the regulation of pollutants emitted into the atmosphere. Coal combustion leads to the vaporization of metals, which subsequently condense as an aerosol of submicron-sized particles. The emission of metals into the atmosphere depends on the vapour pressure of each element (Finkelman et al., 
1990). Trace elements in coals are subdivided into five categories according to the degree of possible health risk (Zhang et al., 2004). The most hazardous metals are: $\mathrm{As}, \mathrm{Cd}, \mathrm{Cr}$ and especially $\mathrm{Hg}$ (Swaine and Goodarzi, 1995). The negative influence of non-metals such as fluorine emitted during indoor combustion of a F-rich coal containing a binder clay has also been observed (Dai et al., 2007).

Mercury begins to be released from coal at temperatures below $200{ }^{\circ} \mathrm{C}$; above $600{ }^{\circ} \mathrm{C}$ it occurs in the form of $\mathrm{Hg}^{0}$ (Mukherjee et al., 2008). For this reason, mercury released into the atmosphere during coal combustion (Yudovich and Ketris, 2005a, 2005b) is a significant pollutant, despite its generally low concentrations in coal (Ketris and Yudovich, 2009; Xu et al., 2013). However, extremely-high Hg concentrations (up to $12.1 \mathrm{ppm}$ ) were reported from some Chinese coals and coal ashes (Dai et al., 2006, 2012a, 2014). Long-range mercury transport, enabled by cycles of deposition and reemission, considerably increases mercury concentrations in subpolar and polar regions (Poissant et al., 2008). This effect is also apparent from the increased levels of mercury in Faroese peat. Maximum concentrations of $498 \mathrm{ppb}$ total $\mathrm{Hg}$ were determined in peat from 1954, at the peak of coal production (Shotyk et al., 2005).

The composition of coal can be affected by volcanic activity. Several authors have studied various properties of thermally altered coal from all over the world (Bussio and Roberts, 2016; Dai and Ren, 2007; Golab and Carr, 2004; Merritt, 1985; Rahman and Rimmer, 2014; Singh et al., 2007, 2008; Wang et al., 2014; Ward et al., 1989; Yao and Liu, 2012). Ward et al. (1989) categorized the layers around an igneous body into four zones: i) zone of porous cinder close to the contact; ii) zone of visibly banded cinder with remnants of the original lithotype stratification; iii) zone of heat-affected coal without porosity and other microscopic and macroscopic signs of coking; iv) zone of unaffected coal. Kwiecińska and Petersen (2004) defined cinder from the contact zone as natural char and coke. Physical and chemical effects of intrusions on peat and coal depend on exposure to heat, time of igneous emplacement, temperature, thickness and form of the igneous body, pressure, hydrology, as well as the composition and initial coal rank of the affected formation, lithology of the surrounding rocks and other local factors (Bostick and Pawlewicz, 1984; Crelling and Dutcher, 1968; Suchý et al., 2002). In heat-affected coal, microconstituents formed by the alteration of vitrinite and liptinite macerals, having different textural and optical properties than the original macerals, are commonly recognized (Taylor et al., 1998). Typical optical changes in coal caused by intrusion/effusion involve microbrecciation, increases in vitrinite reflectance, development of devolatilization pores and fissures, coke textures and the presence of pyrolytic carbon. Pores of natural coke are empty or filled with mineral or carbonaceous matter formed from volatile material (Amijaya and Littke, 2006; Goodarzi and Cameron, 1990; Khorasani et al., 1990; Kisch and Taylor, 1966; Mastalerz et al., 2009; Suchý et al., 2002). The product formed from vitrinite and liptinite of the bituminous coal at temperatures above $500{ }^{\circ} \mathrm{C}$ is an anisotropic coke with a mosaic structure and higher reflectance than the original vitrinite (Kwiecińska and Petersen, 2004).

The goal of this pilot study is threefold: i) to describe the petrography and geochemistry as well as the coal rank of Palaeogene coal from the Faroe Islands; ii) to assess its depositional environment; iii) to characterize the effect of basaltic effusions overlying coal-bearing strata on the coal composition.

\section{Geological setting}

The Faroe Islands were formed during extensive volcanic activity within the North Atlantic Igneous Province in response to the opening of the Atlantic Ocean (Jolley and Bell, 2002). This part of the North Atlantic Igneous Province is named the Faroe Islands Basalt Group and extends to the east and southeast from the current Faroe Islands to the Faroe-Shetland Basin. Volcanic rocks of the Faroe Islands Basalt Group are petrographically classified as aphyric basalts with a fine-grained groundmass, plagioclase-phyric basalts and olivine-phyric basalts (Noe-Nygaard and Rasmussen, 1968).
Rasmussen and Noe-Nygaard $(1969,1970)$ described three tholeiitic basalt series ( $\sim 6.6 \mathrm{~km}$ thick): lower, middle and upper basaltic lava formations that are thought to overlie older continental crust (Bohnhoff and Makris, 2004, Bott et al., 1974; Casten, 1973; Richardson et al., 1998).

The oldest basalt flow yielded an ${ }^{40} \mathrm{Ar} /{ }^{39} \mathrm{Ar}$ plateau age of $63.1 \pm$ 1.8 Ma (Waagstein et al., 2002). After termination of the initial volcanic phase, sediment deposition began. Subsequent volcanic activity produced the middle basaltic lavas and when this ceased, a coal-bearing sedimentary sequence was formed during the period between 58 and $56 \mathrm{Ma}$ (Jolley and Bell, 2002; Storey et al., 2007). Finally, the coalbearing sedimentary sequence was covered by the upper basalt flows.

According to Passey and Jolley (2009), tholeiitic lavas of the Faroe Islands can be further subdivided into seven lithostratigraphic formations (Figs. 1, 2). The basal Lopra Formation (1.1 km thick) is known only from the onshore Lopra-1/1A borehole and consists of basalts, volcaniclastic sandstones and hyaloclastites. The subsequent $3.25-\mathrm{km}-$ thick Beinisvørð Formation is made up of basaltic lavas, volcaniclastics and sandy claystone to mudstone sediments that may contain thin coal lenses. The Beinisvørð Formation is overlain by up to $15 \mathrm{~m}$ thick coal-bearing Prestfjall Formation, deposited between eruptions, which consists predominantly of tuffitic claystones and volcaniclastic conglomerates. The Prestfjall formation is overlain by the syn-eruption Hvannhagi Formation of pyroclastic sediments, up to $50 \mathrm{~m}$ thick. This formation is covered by basaltic lava flows with a total thickness of $1.4 \mathrm{~km}$ named the Malinstindur Formation and the 30-m-thick sedimentary Sneis Formation dominated by sandstones and conglomerates. The volcanic activity terminated with basaltic lava flows forming the 900-m-thick Enni Formation that is interbedded with volcaniclastic sequences. The landscape of the Faroe Islands was subsequently reshaped by Pleistocene glacial activity.

\section{Samples and methods}

To examine the petrological and geochemical composition of Faroese coal, a total of 22 bench samples with well-known positions within the coal-bearing sequence were taken from the Prestfjall Formation on Suðuroy Island and one from the Beinisvørð Formation on Mykines Island (Fig. 1, Table 1). Sampling was performed both in coal mines and coal-bearing sedimentary profiles (Fig. 3A-F), following ISO 50691:1983 standard procedure. The sampled localities were described in detail by Kuboušková et al. (2015). Coal samples were air-dried and stored in polyethylene bags for transport.

Additionally, on Suðuroy Island it was possible to collect basalt samples (Malinstindur Formation; 5 samples) directly overlying the Prestfjall Formation that contains the studied coal occurrences (Fig. 3D, E) and two samples of tuffitic coal-bearing claystone changed to porcelanite along the contact of these formations. Thin sections made from these samples were investigated using an Olympus BX50 petrographic microscope.

\subsection{Petrographic analyses}

The coal samples were the subject of petrographic investigation, i.e., maceral analysis of huminite, liptinite, inertinite groups and mineral group divided into clay minerals, sulphides, carbonates and other particularly accessorial minerals and altered minerals, and measurement of the reflectance of ulminite and altered organic matter (ISO 7404-3: 2009, Taylor et al., 1998).

For petrographic analyses, polished sections were prepared and studied both in reflected and ultraviolet light using an Olympus BX51 microscope with Zeiss Photomultiplier MK3 system and fluorescence mode using immersion lens with $40 \times$ magnification. The Pelcon point counter was used for the maceral analysis. Coal rank was determined by reflectance measurements on ulminite B from particulate polished sections by SpectraVision software calibrated with yttrium aluminium garnet $(R=0.894 \%)$, sapphire $(R=0.596 \%)$, spinel $(R=0.422 \%)$ and 


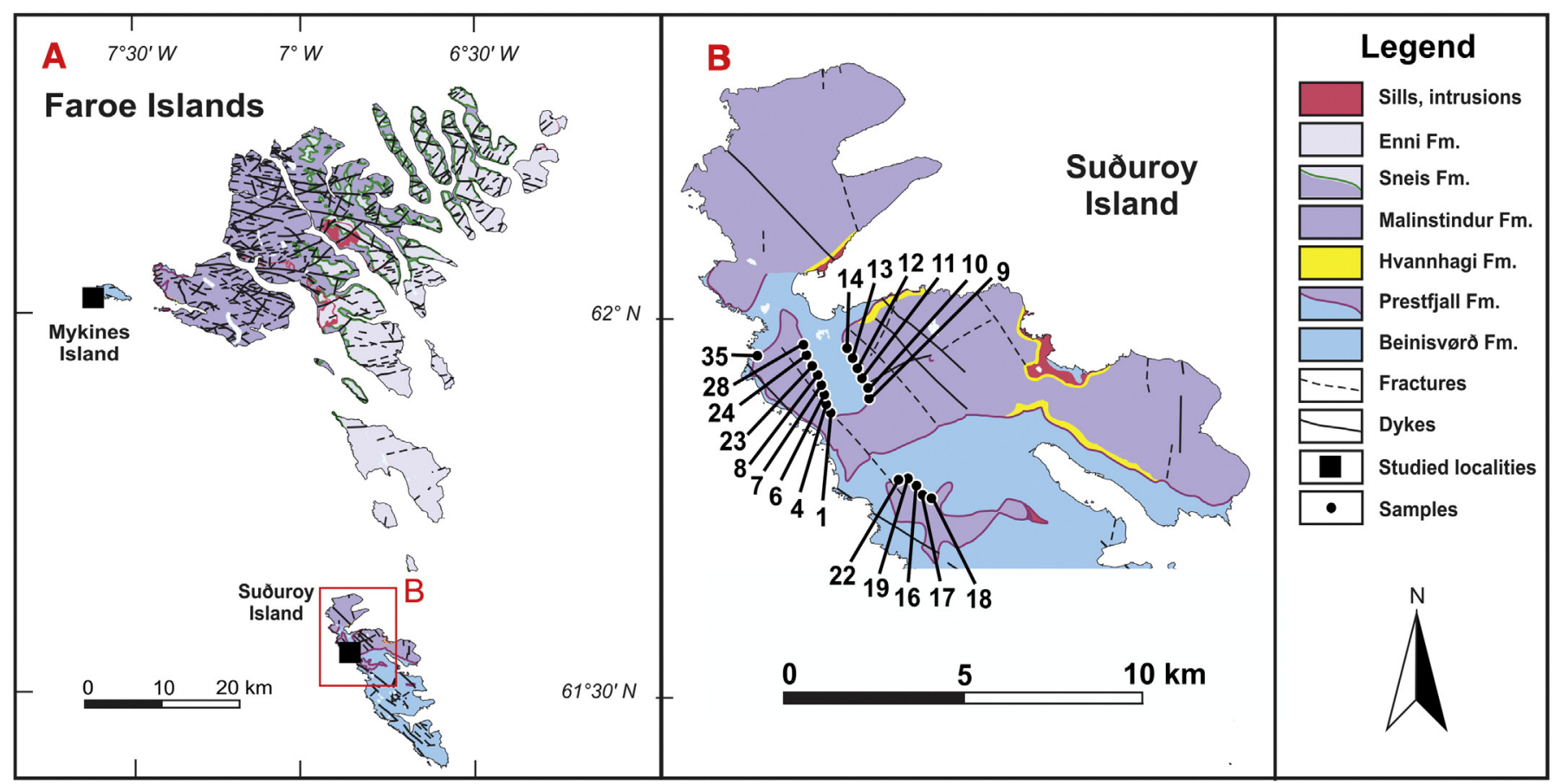

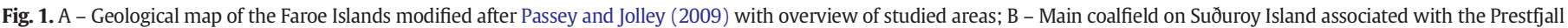
Formation. Numbers of sampled localities correspond with samples ID in tables.

gadolinium-gallium-garnet $(\mathrm{R}=1.717 \%)$ standards. Abbreviations of minerals on photomicrographs were used according to Whitney and Evans (2010).

\subsection{Chemical analyses}

Samples were examined for moisture, ash, elemental composition and calorific values following standard procedures (ČSN 44 1377; ČSN ISO 1171; ČSN ISO 29541). Calorific values were determined by adiabatic bomb calorimetry (Parr 6300 adiabatic bomb calorimeter; Parr Instrument Company, Moline, IL, USA). The ultimate analysis (C, H, N, S and O) was performed using a Thermo Finnigan FA 1112 Series CHNS/O analyzer.

The contents of major oxides and trace elements in the coal were measured by X-ray fluorescence (XRF) spectrometry (Delta Premium). The following certified reference standards were used for calibration of XRF spectrometer for organomineral matrix: GBW07603 (GSV-2) and NIST 2702. Trace amounts of mercury were determined by atomic absorption spectrometry (AAS) using an AMA-254 Advanced Mercury Analyzer (Altec, Czech Republic). The absolute detection limits of this facility are $10 \mathrm{pg} \mathrm{Hg}$. The limit of quantification for $\mathrm{Hg}$ measurements was $0.3 \mathrm{ppb}$ (this limit was defined as $10 \times$ standard deviation of the blank).

From the mercury data, the "Hg coal affinity index" $\left(\mathrm{CAI}_{\mathrm{Hg}}\right)$, which shows how efficiently the coal acted as a crustal geochemical barrier for the mercury, was calculated according to Yudovich and Ketris (2005a) as the ratio of measured $\mathrm{Hg}$ contents in the coal and the average $\mathrm{Hg}$ content in the Upper Continental Crust (UCC) given by Rudnick and Gao (2014):

$\mathrm{CAI}_{\mathrm{Hg}}=\frac{\mathrm{Hg} \text { in the coal }[\mathrm{ppb}]}{50 \mathrm{ppb}(\mathrm{UCC})}$

\section{Results}

The samples investigated in this study represent two distinct groups (Table 1): i) "normal" coal (xylite and detroxylite) and ii) altered organic matter (charcoal and organic particles dispersed in mineralrich samples).

Accordingly, geochemical and organic petrographic signatures were used to compare two different types of the samples. This approach has been applied by evaluating ultimate and proximate analyses, maceral descriptions and inorganic geochemical compositions.

\subsection{Field and macroscopic characteristics}

The thicknesses of the coal seams range from a few centimetres to $1.5 \mathrm{~m}$, the thicker of which have been exploited in coal mines (Fig. 3A, $B$ ). The studied coal varies from xylitic, containing relict wooden fragments (SK14B), to a compact, "anthracite-like" character with a noticeable resinous lustre and conchoidal fracture (e.g., SK01, SK22). However, the "anthracite-like" character of the coal appears only at the surface of several samples (Fig. 3C). The coal is covered by limonite in places and cubic crystals of pyrite were occasionally observed.

\subsection{Ultimate and proximate parameters}

The ultimate and proximate analyses illustrate the variability of the sample groups (Table 2, Fig. 4A-C). Overall ranges (in wt.\%) were 5.63 to 71.5 for total carbon $\left(C^{\mathrm{d}}\right), 1.43$ to 5.13 for total hydrogen $\left(\mathrm{H}^{\mathrm{d}}\right), 0.03$ to 0.99 for total sulphur $\left(\mathrm{S}^{\mathrm{d}}\right), 0.05$ to 0.83 for total nitrogen $\left(\mathrm{N}^{\mathrm{d}}\right)$ and 7.46 to 25.89 for total oxygen $\left(\mathrm{O}^{\mathrm{d}}\right)$.

Samples classified as "altered organic matter" (except of charcoal) have elevated ash yields $\left(\mathrm{A}^{\mathrm{d}}\right)$ between 74.05 and $86.2 \mathrm{wt} . \%$, very low calorific value $\left(Q_{s}^{d}\right) 0.75-3.2 \mathrm{MJ} / \mathrm{kg}$ along with very high content of volatile compounds ( $\mathrm{V}^{\text {daf }}$ ) 43.51-96.17 wt.\%. In contrast, charcoal and samples classified as "normal" coal have medium to high $\mathrm{V}^{\text {daf }}$ (30.11-45.31 wt.\%), and relatively high $\mathrm{Q}_{\mathrm{s}}^{\mathrm{d}}(23.80-29.06 \mathrm{MJ} / \mathrm{kg}$ ) accompanied by low to medium $\mathrm{A}^{\mathrm{d}}$ (2.26-18.71 wt.\%).

The carbon content $\left(C^{d}\right)$ was chosen as the primary parameter for coals due to its slight separation potential. Subsequently, correlation with hydrogen and oxygen content was carried out (Fig. 4A, B). All 18 samples classified as a "normal" coal are thermally immature and belong to low-rank, respectively lignite to subbituminous stage (ECE-UN, 1998). 
Thick sedimentary beds $(>15 \mathrm{~m})$ - Thin sedimentary layers $(<15 \mathrm{~m})$ No data

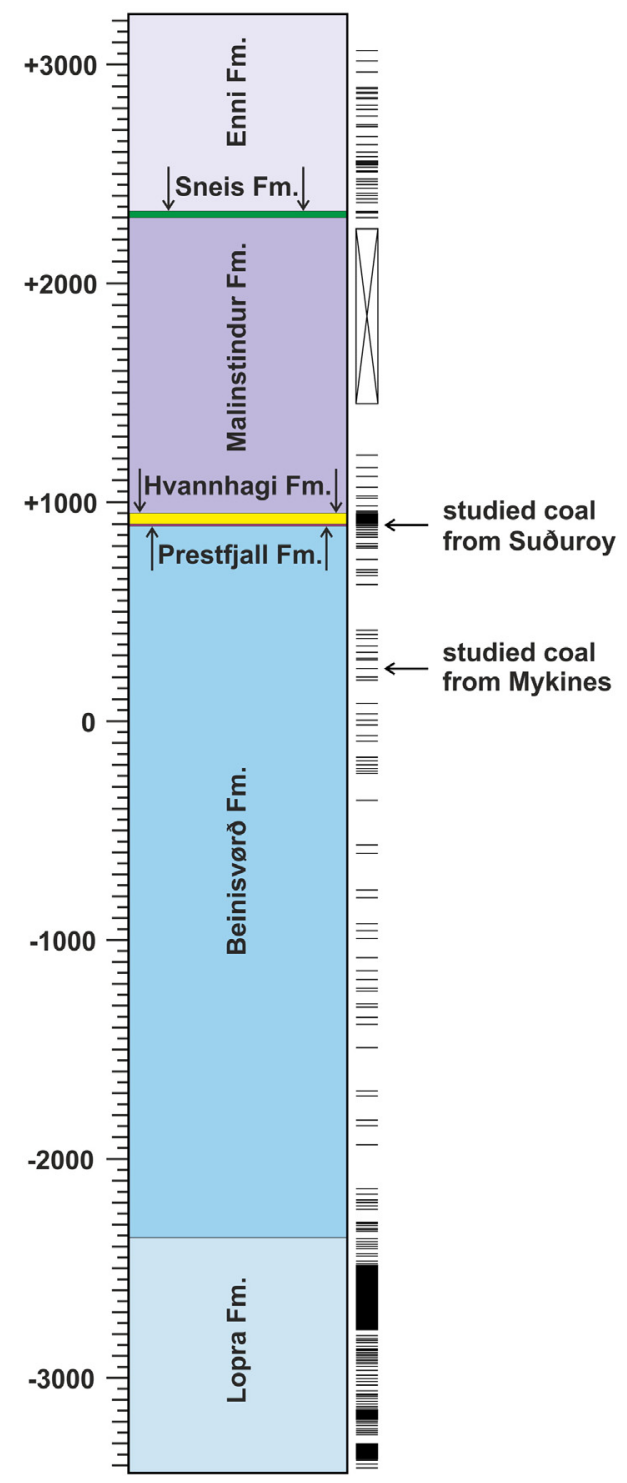

Fig. 2. Litostratigraphic subdivision of the Faroe Islands Basalt Group. Volcaniclastic sediment layers are highlighted on the right side of the scheme together with positions of studied coal-bearing sequences (Pokorný et al., 2015, modified). Position of sampled coal-bearing strata on Mykines Island was correlated with a study of Passey and Varming (2010). Negative stratigraphic profile is inferred from Lopra-1/1A borehole.

\subsection{Coal petrography}

Precise characterization of coal and coaly material has been successfully achieved by the investigating of individual macerals (e.g., Taylor et al., 1998). Maceral descriptions focused partly on specific alteration features, and gelification related to changes in maceral composition was evaluated (Fig. 5, Table 3). Maceral analysis allowed discrimination of various sample types. In particular, xylite, detroxylite, charcoal and organic particles dispersed in mineral matter could be distinguished.

\subsubsection{Maceral composition}

All "normal" coal samples are classified as a gelified xylite-rich coal. The fossil wood remnants in these coals contain mainly huminite macerals (55.7-97 vol.\%) of predominantly ulminite B (38.9-93 vol.\%)
Table 1

List of coal samples and their geographic locations.

\begin{tabular}{|c|c|c|c|c|c|}
\hline $\begin{array}{l}\text { Sample } \\
\text { ID }\end{array}$ & $\begin{array}{c}\text { Sample } \\
\text { type }\end{array}$ & Locality & Island & $\begin{array}{l}\text { Longitude } \\
\text { (N) }\end{array}$ & $\begin{array}{l}\text { Latitude } \\
\text { (W) }\end{array}$ \\
\hline SK01A & xylite & New Prestfjall mine & Suðuroy & $61^{\circ} 34^{\prime} 9.7^{\prime \prime}$ & $6^{\circ} 56^{\prime} 4.6^{\prime \prime}$ \\
\hline SK01B & detroxylite & New Prestfjall mine & Suðuroy & $61^{\circ} 34^{\prime} 9.7^{\prime \prime}$ & $6^{\circ} 56^{\prime} 4.6^{\prime \prime}$ \\
\hline SK01C & detroxylite & New Prestfjall mine & Suðuroy & $61^{\circ} 34^{\prime} 9.7^{\prime \prime}$ & $6^{\circ} 56^{\prime} 4.6^{\prime \prime}$ \\
\hline SK04 & detroxylite & Kolaminur & Suðuroy & $61^{\circ} 34^{\prime} 12^{\prime \prime}$ & $6^{\circ} 56^{\prime} 10.3^{\prime \prime}$ \\
\hline SK06 & xylite & Kolaminur & Suðuroy & $61^{\circ} 34^{\prime} 18.6^{\prime \prime}$ & $6^{\circ} 56^{\prime} 15.3^{\prime \prime}$ \\
\hline SK07 & detroxylite & Kolaminur & Suðuroy & $61^{\circ} 34^{\prime} 21.3^{\prime \prime}$ & $6^{\circ} 56^{\prime} 14.5^{\prime \prime}$ \\
\hline SK08 & detroxylite & Kolaminur & Suðuroy & $61^{\circ} 34^{\prime} 25.4^{\prime \prime}$ & $6^{\circ} 56^{\prime} 13.5^{\prime \prime}$ \\
\hline SK09 & detroxylite & Rókhagi & Suðuroy & $61^{\circ} 34^{\prime} 31.9^{\prime \prime}$ & $6^{\circ} 55^{\prime} 0.9^{\prime \prime}$ \\
\hline SK10 & mineral-rich & Rókhagi & Suðuroy & $61^{\circ} 34^{\prime} 39.2^{\prime \prime}$ & $6^{\circ} 55^{\prime} 9.4^{\prime \prime}$ \\
\hline SK12 & detroxylite & Rókhagi & Suðuroy & $61^{\circ} 34^{\prime} 41.7^{\prime \prime}$ & $6^{\circ} 55^{\prime} 13.1^{\prime \prime}$ \\
\hline SK13 & detroxylite & Rókhagi & Suðuroy & $61^{\circ} 34^{\prime} 44.4^{\prime \prime}$ & $6^{\circ} 55^{\prime} 17.8^{\prime \prime}$ \\
\hline SK14A & xylite & Rókhagi & Suðuroy & $61^{\circ} 34^{\prime} 46.4^{\prime \prime}$ & $6^{\circ} 55^{\prime} 19.8^{\prime \prime}$ \\
\hline SK14B & charcoal & Rókhagi & Suðuroy & $61^{\circ} 34^{\prime} 46.4^{\prime \prime}$ & $6^{\circ} 55^{\prime} 19.8^{\prime \prime}$ \\
\hline SK16 & xylite & Rangibotnur & Suðuroy & $61^{\circ} 33^{\prime} 11.4^{\prime \prime}$ & $6^{\circ} 53^{\prime} 44.2^{\prime \prime}$ \\
\hline SK17 & xylite & Rangibotnur & Suðuroy & $61^{\circ} 33^{\prime} 9.4^{\prime \prime}$ & $6^{\circ} 53^{\prime} 43.1^{\prime \prime}$ \\
\hline SK18 & detroxylite & Rangibotnur & Suðuroy & $61^{\circ} 33^{\prime} 2.7^{\prime \prime}$ & $6^{\circ} 53^{\prime} 30.6^{\prime \prime}$ \\
\hline SK19 & xylite & Gudmund's mine & Suðuroy & $61^{\circ} 33^{\prime} 16.7^{\prime \prime}$ & $6^{\circ} 53^{\prime} 48.6^{\prime \prime}$ \\
\hline SK22 & xylite & Gudmund's mine & Suðuroy & $61^{\circ} 33^{\prime} 17.1^{\prime \prime}$ & $6^{\circ} 54^{\prime} 10.6^{\prime \prime}$ \\
\hline SK23 & mineral-rich & Kolavegurin & Suðuroy & $61^{\circ} 34^{\prime} 31.4^{\prime \prime}$ & $6^{\circ} 56^{\prime} 15.3^{\prime \prime}$ \\
\hline SK24 & mineral-rich & Kolavegurin & Suðuroy & $61^{\circ} 34^{\prime} 33.9^{\prime \prime}$ & $6^{\circ} 56^{\prime} 16.2^{\prime \prime}$ \\
\hline SK28 & detroxylite & Kolavegurin & Suðuroy & $61^{\circ} 34^{\prime} 42^{\prime \prime}$ & $6^{\circ} 56^{\prime} 22.9^{\prime \prime}$ \\
\hline SK35 & mineral-rich & Suður í Haga & Suðuroy & $61^{\circ} 35^{\prime} 08^{\prime \prime}$ & $6^{\circ} 58^{\prime} 14.2^{\prime \prime}$ \\
\hline SK40 & xylite & Mykineshólmur & Mykines & $62^{\circ} 06^{\prime} 01.1^{\prime \prime}$ & $7^{\circ} 39^{\prime} 41.4^{\prime \prime}$ \\
\hline
\end{tabular}

with poorly discernible tissue structures, and less densinite (1.7-11.7 vol.\%). Light grey ulminite B dominates in all samples and forms a homogenous groundmass in most coals, whereas contents of darker grey ulminite A with reflectance values between 0.25 and $0.33 \%$ do not exceed 2 vol.\% in samples SK01B, SK06, SK13, SK28 and SK40. Most corpohuminite (1.8-9.9 vol.\%) occurs in-situ in wood and bark tissues as phlobaphinite (Fig. 6A, B, C), smaller amounts may also occur dispersed in densinite or in clay minerals. Corpohuminite is formed in well-preserved oval to elongated (compressed) cell structures that can be gas-charged or filled by mineralization products, as very well developed in sample SK40. Textinite is irregularly distributed and its content is relatively low (up to 6.4 vol.\% in sample SK12). Gelinite was not found.

Liptinite contents vary between 1.5 vol.\% and 25.5 vol.\%. This maceral group is dominated by resinite (1.1-11.2 vol.\%), and less cutinite (0.3-8 vol.\%), liptodetrinite (0.8-4.4 vol.\%), sporinite (0.7-5.3 vol.\%) and suberinite (0.4-3.6 vol.\%). Resinite mostly occurs in-situ in wood cell tissues and leaf fragments (Fig. 6B, C, D). Small isolated resinite bodies commonly forms greyish rounded or elongated grains which are often slightly altered and show weak yellow to brown fluorescence and often contain fine pores as result of degassing. Resinite is mostly dispersed in densinite and clay minerals. Cutinite is predominantly derived from coniferous leaves that are variable deformed and humified. Fragments of separate tenuicutinite were identified only in a few samples SK01C, SK06, SK08, SK13 and SK28 (Fig. 6D). Liptodetrinite occurs as long bands, individually as small nests or dispersed in densinite and clay minerals. Sporinite appears most frequently as dark brown oval structures within liptodetrinite. Suberinite was often found in bark tissues and less in rootlet cortex together with phlobaphinite (Fig. 6C).

Inertinite contents vary between 0.9 vol.\% and 23 vol.\% and is represented predominantly by fusinite, macrinite, semifusinite and inertodetrinite. Secretinite and funginite are rare. Whereas macrinite occurs mainly as irregularly shaped particles of $>10 \mu \mathrm{m}$ size (Fig. $6 \mathrm{E}$ ), inertodetrinite appears as discrete $<10 \mu \mathrm{m}$ sized fragments. In mineral-rich samples (SK10, SK23, SK24) it can occur dispersed throughout the mineral mass.

Mineral matter contents range between 1.5 vol.\% and 30.2 vol.\% in xylite-rich coal. Compositions of mineral matter are very variable, particularly in samples SK01B and SK04. Mineral admixture consists 

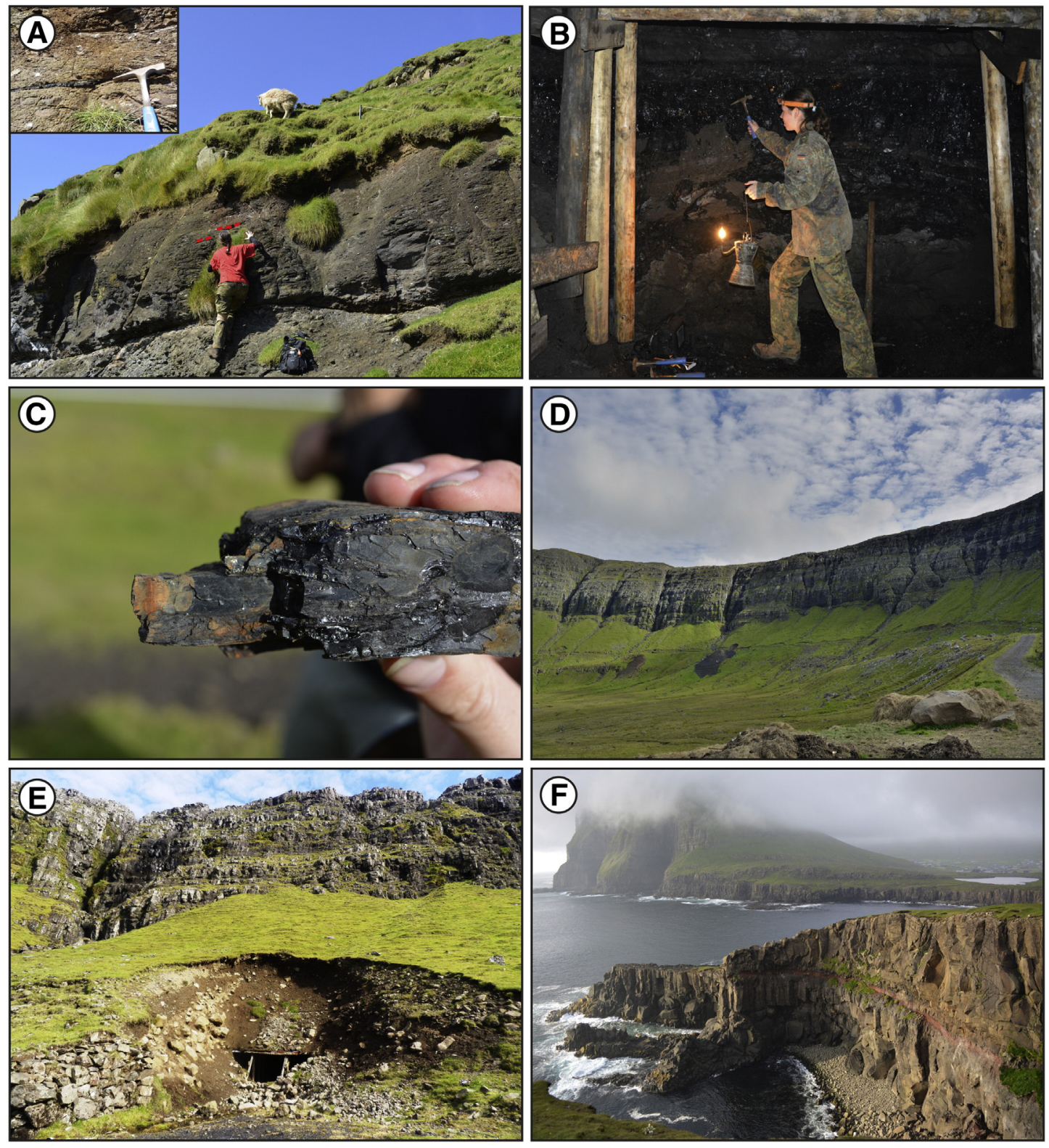

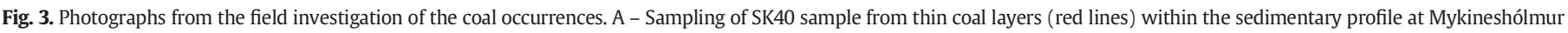

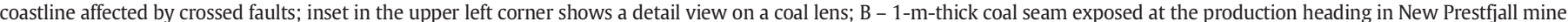

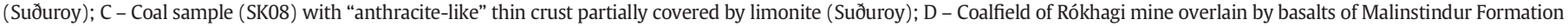
(Suðuroy); E - Partially buried adit portal of Rókhagi mine (Suðuroy). F - Reddish coal-bearing sedimentary sequence exposed at Hvalba cliffs, Suður í Haga (Suðuroy).

primarily of fine-grained clay minerals, especially smectites and kaolinites (Parra et al., 1987), which are dispersed in fine-grained densinite, or form isolated layers (Fig. 6E, F). Pyrite appears either as fracture fillings of epigenetic origin (Fig. 7A), or as syngenetic framboidal globules and aggregates (Fig. 7B) in amounts not exceeding 3 vol.\%, particularly in samples SK12 and SK13. Quartz and carbonates occur irregularly and their contents do not exceed 3 vol.\% in "normal" coal. Carbonates are predominantly siderite and calcite with well-shaped crystals showing noticeable cleavage. The coal can be slightly oxidized, which becomes evident at the margins of huminite grains as 10-20 $\mu$ m thick oxidized rims of darker grey colour, or as a thin limonite crust. The mineral composition of xylite-rich coal is quite unusual. Various minerals which could not be identified using microscopic techniques were included into the group "other" (Table 3 ).

All samples of "altered organic matter" (SK10, SK14B, SK23, SK24 and SK35) are altered with respect of their mineral and organic content
(Fig. 8A-D). Organic material consists mainly of altered particles of huminite and inertinite (average reflectance $0.56-1.35 \%$ ) and char particles with the highest average reflectance of $1.93 \%$ (Fig. 8C, D). Rarely present are unaltered particles of ulminite with average reflectance of $0.39-0.42 \%$ (Fig. 8B) and inertinite. The most common minerals observed in samples grouped into "altered organic matter" are clay minerals, indicating a transition from pure coal to coaly claystone. The interesting charcoal sample SK14B (Fig. 8A) consists of altered textinite and ulminite with corpohuminite lacking resinite, respectively fusinite and semifusinite within a fine-grained clayey matrix. Altered wood material in this sample has reflectance values of up to $0.87 \%$ (Table 4 ).

\subsubsection{Coal rank}

The random reflectance values $\left(\mathrm{R}_{\mathrm{r}}\right)$ of ulminite $\mathrm{B}$ in "normal" coal range from $0.34 \%$ to $0.53 \%$ with standard deviation in the range 
Table 2

Ultimate and proximate analyses of Faroese samples.

\begin{tabular}{|c|c|c|c|c|c|c|c|c|c|}
\hline Sample ID & w $^{\mathrm{a}}$ [wt.\%] & $\mathrm{A}^{\mathrm{d}}[\mathrm{wt} . \%]$ & $\mathrm{Q}_{\mathrm{s}}^{\mathrm{d}}[\mathrm{MJ} / \mathrm{kg}]$ & $\mathrm{H}^{\mathrm{d}}$ [wt.\%] & $\mathrm{N}^{\mathrm{d}}$ [wt.\%] & $\mathrm{C}^{\mathrm{d}}$ [wt.\%] & $S^{\mathbf{d}}$ [wt.\%] & $\mathbf{O}^{\mathrm{d}}$ [wt.\%] & $\mathrm{V}^{\text {daf }}$ [wt.\%] \\
\hline SK01A & 8.52 & 4.53 & 28.96 & 4.53 & 0.75 & 69.62 & 0.38 & 20.19 & 35.74 \\
\hline SK01B & 8.44 & 18.71 & 23.80 & 4.36 & 0.48 & 56.15 & 0.42 & 19.88 & 45.31 \\
\hline SK01C & 6.90 & 12.50 & 26.03 & 4.78 & 0.62 & 62.89 & 0.46 & 18.78 & 43.42 \\
\hline SK04 & 9.69 & 3.47 & 29.01 & 4.78 & 0.66 & 71.24 & 0.29 & 19.56 & 36.43 \\
\hline SK06 & 9.73 & 2.64 & 29.06 & 4.61 & 0.72 & 71.22 & 0.28 & 20.53 & 37.85 \\
\hline SK07 & 10.15 & 3.90 & 28.36 & 5.02 & 0.56 & 67.30 & 0.42 & 22.80 & 38.20 \\
\hline SK08 & 9.22 & 14.60 & 24.52 & 4.24 & 0.61 & 61.21 & 0.22 & 19.11 & 42.97 \\
\hline SK09 & 9.91 & 2.39 & 28.87 & 4.21 & 0.58 & 66.89 & 0.11 & 25.89 & 35.79 \\
\hline SK10 & 2.97 & 86.20 & 0.75 & 1.43 & 0.10 & 2.38 & 0.03 & 9.91 & 96.17 \\
\hline SK12 & 10.2 & 2.26 & 28.97 & 4.63 & 0.60 & 71.49 & 0.23 & 20.79 & 36.23 \\
\hline SK13 & 8.85 & 8.41 & 27.14 & 4.67 & 0.61 & 66.98 & 0.99 & 18.34 & 37.79 \\
\hline SK14A & 10.12 & 5.35 & 27.84 & 5.10 & 0.52 & 66.56 & 0.57 & 21.90 & 36.37 \\
\hline SK14B & 4.62 & 12.30 & 26.63 & 3.67 & 0.25 & 69.08 & 0.03 & 14.65 & 30.11 \\
\hline SK16 & 9.71 & 2.46 & 28.95 & 4.77 & 0.33 & 71.50 & 0.17 & 20.77 & 37.38 \\
\hline SK17 & 9.08 & 5.43 & 27.40 & 5.13 & 0.44 & 65.60 & 0.61 & 22.79 & 38.39 \\
\hline SK18 & 9.09 & 3.53 & 28.32 & 4.71 & 0.44 & 70.49 & 0.25 & 20.58 & 37.51 \\
\hline SK19 & 9.57 & 7.97 & 25.80 & 4.80 & 0.62 & 62.27 & 0.53 & 23.81 & 39.51 \\
\hline SK22 & 10.43 & 4.99 & 27.82 & 4.53 & 0.83 & 68.47 & 0.43 & 20.75 & 35.91 \\
\hline SK23 & 3.76 & 74.05 & 3.25 & 1.45 & 0.12 & 16.85 & 0.07 & 7.46 & 43.51 \\
\hline SK24 & 3.70 & 85.26 & 0.78 & 1.44 & 0.09 & 5.63 & 0.03 & 7.55 & 88.40 \\
\hline SK28 & 9.83 & 5.06 & 27.20 & 4.82 & 0.50 & 65.81 & 0.46 & 23.35 & 37.95 \\
\hline SK35 & 8.72 & 82.67 & 2.44 & 1.89 & 0.05 & 7.06 & 0.16 & 8.17 & 43.68 \\
\hline SK40 & 10.49 & 11.94 & 23.82 & 4.90 & 0.64 & 57.07 & 0.24 & 25.21 & 44.02 \\
\hline
\end{tabular}

W - moisture

A - ash yield

$\mathrm{Q}_{\mathrm{s}}$ - gross calorific value

$\mathrm{V}$ - volatile matter

a - Analytical sample

d - Dry basis

daf - Dry, ash free basis
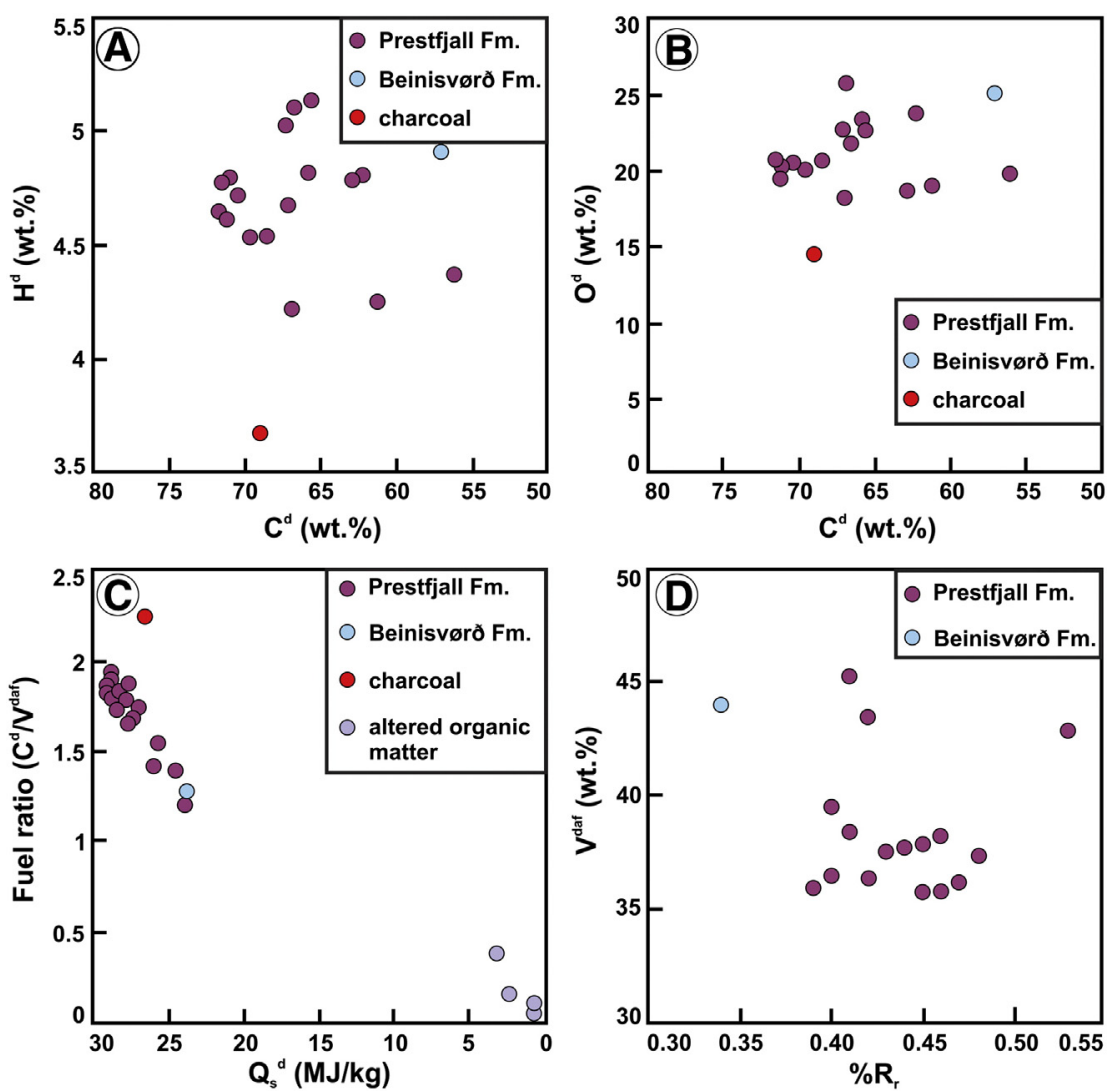

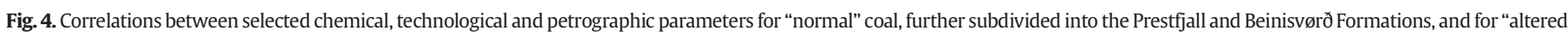

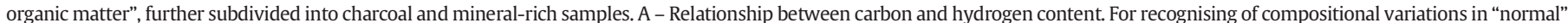

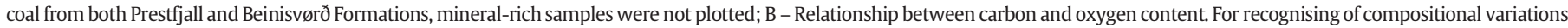

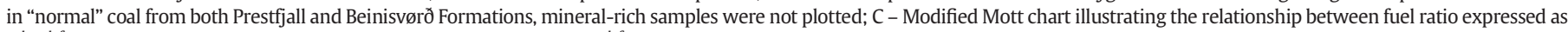
$\mathrm{C}^{\mathrm{d}} / \mathrm{V}^{\mathrm{daf}}$ and calorific value; $\mathrm{D}$ - Relationship between volatile matter $\left(\mathrm{V}^{\mathrm{daf}}\right)$ and mean ulminite reflectance $\left(\mathrm{R}_{\mathrm{r}}\right)$ for the studied samples from the Faroe Islands. 

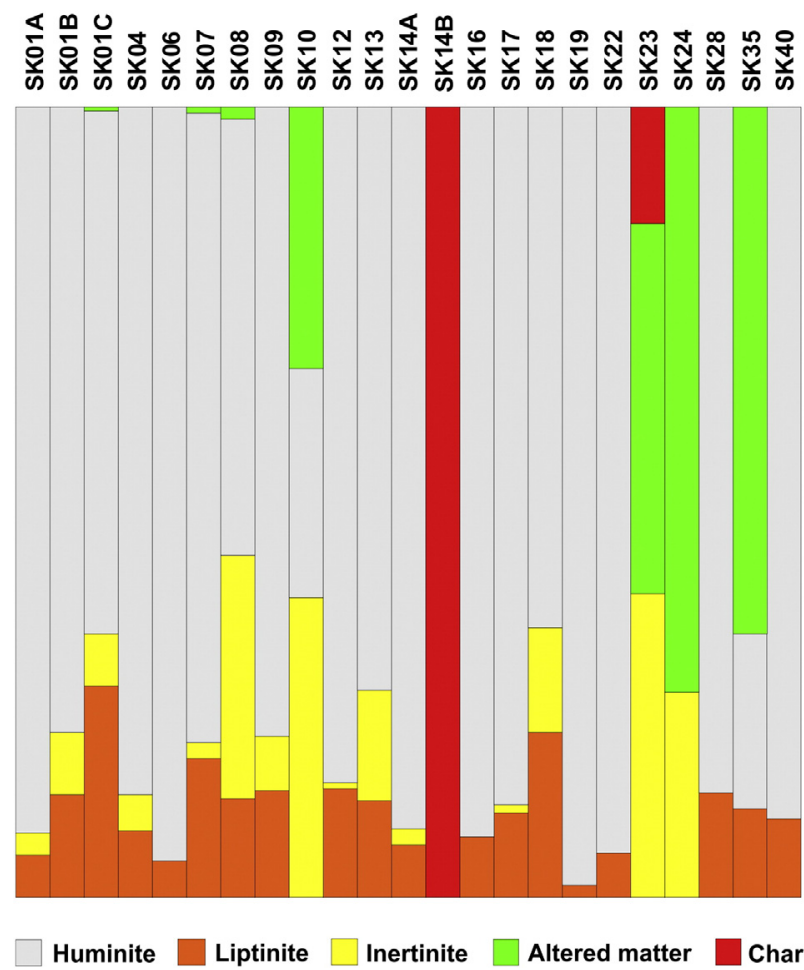

Fig. 5. Histogram based on the maceral analysis showing a ratio of macerals from the huminite, liptinite and inertinite group, altered organic paticles and char particles. For recognising of relationships within the organic matter, mineral mass was not included in this diagram.

0.04-0.09, suggesting that the coal rank of samples from the Faroe Islands is between lignite and subbituminous coal according to the ECE-UN (1998) standard. Ulminite reflectance for the group of "altered organic matter" samples varies between 0.39 and $0.83 \% \mathrm{R}_{\mathrm{r}}$. These samples have low concentrations of unaltered organic matter, especially measurable ulminite particles. Thus, the ulminite reflectance measurements allow only tentative rank evaluations of these samples. For this reason, reflectance measurements were performed on altered and charred particles with average values ranging from $0.56 \%$ to $1.93 \%$, suggesting that the reflectance increases along with thermal alteration of organic matter (Table 4).

\subsection{Petrographic features of basaltic lava in contact with underlying tuffitic coal-bearing claystone}

The volcanic rocks are very fine-grained, massive, dark-grey basalts. The absence of features such as pillow lavas or hyaloclastic breccias suggests subaerial volcanic activity (Smellie et al., 2008 and references therein). The basalts are composed of thin plagioclase laths $(<100 \mu \mathrm{m})$ frequently associated with clinopyroxene and/or altered olivine in the form of larger glomerophyres (Fig. 9A). Plagioclase zones with higher anorthite mole fractions are selectively affected by alteration (Fig. 9A). Additionally, some samples are characterised by the occurrence of interstitial glass, tachylyte, suggesting relatively rapid cooling of the lava flow. Tachylyte shows various stages of alteration ranging from nearly opaque to orange-brown in colour (Fig. 9B). In tuffitic coal-bearing claystone from the contact of the Prestfjall and Malinstindur Formation, fragments of older basaltic volcanites altered to clay minerals were observed (Fig. 9C). Along the contact, this claystone was thermally metamorphosed to porcelanite and penetrated by a system of hydrothermal veinlets, which led to alteration of plagioclase laths (Fig. 9D).

\subsection{Geochemical composition}

\subsubsection{Major oxides}

Major element oxides compositions in all samples are represented mainly by $\mathrm{SiO}_{2}, \mathrm{Al}_{2} \mathrm{O}_{3}$, and $\mathrm{Fe}_{2} \mathrm{O}_{3}^{\text {tot }}$. $\mathrm{SiO}_{2}$ contents range between 0.9 and $8.6 \mathrm{wt}$.\% for the majority of "normal" coal samples (Table 5). In "altered organic matter", the amount of $\mathrm{SiO}_{2}$ reaches as high as $37.1 \mathrm{wt} . \%$. "Normal" coal samples are characterized by variable amounts of $\mathrm{Al}_{2} \mathrm{O}_{3}$ that range from 0.8 to 8.4 wt.\%, whereas "altered organic matter" samples show significantly elevated contents of up to $25.1 \mathrm{wt}$.\%. The concentration of $\mathrm{Fe}_{2} \mathrm{O}_{3}^{\text {tot }}$ does not exceed $5.1 \mathrm{wt}$ \% in any sample, with the exception of sample SK35 (16.1 wt.\%.). CaO contents are generally below 3.5 wt.\%. MnO contents (up to 2.9 wt.\%) are elevated only in "altered organic matter". Additionally, the sample from the Beinisvørð Formation has a measurable concentration of $\mathrm{P}_{2} \mathrm{O}_{5}(0.4 \mathrm{wt}$.\%), while the levels of $\mathrm{K}_{2} \mathrm{O}$ and $\mathrm{MgO}$ are below their detection limits in the majority of samples.

\subsubsection{Trace elements}

In comparison with the worldwide average composition of low-rank coal (Ketris and Yudovich, 2009), samples from the Faroe Islands are relatively depleted in $\mathrm{Sr}$ (19 ppm on average), $\mathrm{Zr}$ (13 ppm on average) and As (2 ppm on average) and enriched in V (286 ppm on average), W (92 ppm on average), Cu (99 ppm on average) and Se (6 ppm on average). The coal sample from the older Beinisvørð Formation differs in its higher Rb, Sr, W and Ni contents (Fig. 10; Table 6). The "altered organic matter" samples show similar enrichment trends for $\mathrm{Rb}, \mathrm{Sr}, \mathrm{Zr}, \mathrm{V}, \mathrm{Cu}$ and especially for $\mathrm{Cr}$ (up to $126 \mathrm{ppm}$ ) and $\mathrm{Ni}$ (up to $291 \mathrm{ppm}$ ).

\subsubsection{Mercury contents}

The precise determination of mercury contents revealed that the majority of coal samples typically have concentrations between 22 and $210 \mathrm{ppb}$ (Table 7). This places the mercury concentrations are both below and well above the worldwide average $\mathrm{Hg}$ content of 100 ppb Hg (Ketris and Yudovich, 2009). In contrast, "altered organic matter" has very low mercury values ( $<10 \mathrm{ppb})$. The sample from the older Beinisvørð Formation also yields a low $\mathrm{Hg}$ value of $14 \mathrm{ppb}$.

\section{Discussion}

\subsection{Degree of coalification}

The samples from the Faroe Islands classified in this work as "normal" coal have very low mean ulminite reflectance corresponding to the lignite and subbituminous stages. The samples classified as "altered organic matter" were affected by alteration related to the adjacent volcanic activity. Although these samples macroscopically resemble a detroxylitic coal, they actually correspond, in terms of their carbon content, to coaly claystones rich in altered clastic mineral component. These samples contain rare unaltered particles of ulminite with an average reflectance of $0.39-0.42 \%$, suggesting their original low rank. The altered huminite, inertinite and char particles have reflectance values up to $1.93 \%$, corresponding to slight thermal alteration (Table 4 ).

Mineralization of the coal appears to affect its quality, as shown by the correlation between increasing mineralization (ash yield) and decreasing carbon content and gross calorific value, as noted by Liu et al. (2005). This results from the release and migration of organic matter and subsequent precipitation of epigenetic minerals produced by hydrothermal fluids (Chen et al., 2014).

Samples SK40, SK01B, SK01C, SK08 and SK13 plot outside the trend followed by other studied "normal" coals in the O/C diagram (Fig. 4B). Specifically, the samples have lower oxygen percentages than might be expected for their carbon contents (e.g., Gurba and Ward, 2000). These samples also all have relatively higher mineral contents compared to other coals, but not so extremely high such as in the samples grouped into "altered organic matter". 
Table 3

Result of maceral analysis and calculated facies indices.

\begin{tabular}{|c|c|c|c|c|c|c|c|c|c|c|c|c|}
\hline Macerals [vol.\%] & SK01A & SK01B & SK01C & SK04 & SK06 & SK07 & SK08 & SK09 & SK10 & SK12 & SK13 & SK14A \\
\hline Ulminite & 78.7 & 64.2 & 38.9 & 76.3 & 82.6 & 66.4 & 34.7 & 47 & 2.7 & 68.1 & 52.3 & 85.1 \\
\hline Textinite & 0.3 & 0.8 & 0 & 0.9 & 1.4 & 1.9 & 0 & 1.3 & 0 & 6.4 & 0 & 0 \\
\hline Densinite & 3.1 & 6.8 & 11.4 & 0 & 2.2 & 0 & 3.2 & 4 & 3.2 & 0 & 6.3 & 0 \\
\hline Corpohuminite & 1.8 & 0.9 & 6.3 & 2.7 & 5.1 & 9.9 & 3.2 & 3.4 & 0.3 & 5.6 & 3.1 & 3.8 \\
\hline Attrinite & 0 & 0 & 2.9 & 0 & 0 & 0 & 0 & 0 & 0 & 0 & 0 & 0 \\
\hline Huminite & 83.9 & 72.7 & 59.5 & 79.9 & 91.3 & 78.2 & 41.1 & 55.7 & 6.2 & 80.1 & 61.7 & 88.9 \\
\hline Sporinite & 0.7 & 1.8 & 0.7 & 3 & 0 & 3 & 2.2 & 3.3 & 0 & 2.1 & 1.6 & 0.9 \\
\hline Suberinite & 0 & 1.2 & 2.9 & 0.4 & 0 & 0.6 & 1 & 0 & 0 & 0 & 1.4 & 0 \\
\hline Resinite & 1.1 & 4.5 & 8.7 & 1.5 & 4.3 & 9.1 & 2 & 2.7 & 0 & 9.3 & 2.3 & 3.8 \\
\hline Liptodetrinite & 2.8 & 4.3 & 3.8 & 2.2 & 0 & 4 & 4 & 3.4 & 0 & 1.4 & 4.2 & 1.8 \\
\hline Cutinite & 0.3 & 0 & 8 & 0.5 & 0 & 0.4 & 0 & 0 & 0 & 0 & 0.7 & 0 \\
\hline Liptinite & 4.9 & 11.8 & 24.1 & 7.6 & 4.3 & 17.1 & 9.2 & 9.4 & 0 & 12.8 & 10.2 & 6.5 \\
\hline Fusinite & 0.8 & 1.8 & 1.3 & 0.7 & 0 & 0 & 7.5 & 0.7 & 0.8 & 0 & 1.5 & 0 \\
\hline Semifusinite & 1.7 & 2.3 & 0.8 & 1.4 & 0 & 0 & 4.3 & 0.8 & 2.1 & 0.7 & 2.9 & 0 \\
\hline Secretinite & 0 & 0.5 & 0 & 0 & 0 & 0 & 0 & 0 & 0 & 0 & 0 & 0 \\
\hline Macrinite & 0 & 1 & 1.1 & 0.8 & 0 & 1 & 4.7 & 0.8 & 2.1 & 0 & 4.2 & 0.8 \\
\hline Inertodetrinite & 0 & 1.7 & 2.7 & 1.3 & 0 & 1 & 6.5 & 2.4 & 3.1 & 0 & 2.5 & 1 \\
\hline Funginite & 0 & 0 & 0 & 0 & 0 & 0 & 0 & 0 & 0 & 0 & 0.6 & 0 \\
\hline Inertinite & 2.5 & 7.3 & 5.9 & 4.2 & 0 & 2 & 23 & 4.7 & 8.1 & 0.7 & 11.7 & 1.8 \\
\hline Clay minerals & 7.1 & 5.9 & 3.1 & 3.5 & 0.8 & 1.1 & 19.1 & 20.1 & 49.2 & 1.8 & 7 & 1.9 \\
\hline Pyrite & 0.3 & 0.4 & 2.2 & 0 & 0.5 & 0 & 0 & 0.7 & 0 & 1.4 & 5.9 & 0 \\
\hline Carbonates & 0.2 & 0.9 & 0.6 & 0.5 & 0 & 0.2 & 2.1 & 1.4 & 11.4 & 0.7 & 0.6 & 0 \\
\hline Limonite & 0 & 0 & 0 & 0.5 & 1.5 & 0 & 0 & 1 & 0 & 2.5 & 0 & 0 \\
\hline Quartz & 0 & 0 & 0.5 & 0.6 & 0 & 0 & 1.1 & 2.7 & 4.8 & 0 & 0.5 & 0 \\
\hline Others & 1.1 & 1 & 3.6 & 3.2 & 1.6 & 0.8 & 3.3 & 4.3 & 13.2 & 0 & 2.4 & 0.9 \\
\hline Minerals & 8.7 & 8.2 & 10 & 8.3 & 4.4 & 2.1 & 25.6 & 30.2 & 78.6 & 6.4 & 16.4 & 2.8 \\
\hline Alteration [vol.\%] & 0 & 0 & 0.5 & 0 & 0 & 0.6 & 1.2 & 0 & 7.1 & 0 & 0 & 0 \\
\hline Char [vol.\%] & 0 & 0 & 0 & 0 & 0 & 0 & 0 & 0 & 0 & 0 & 0 & 0 \\
\hline MACERALS [vol.\%] & SK14B & SK16 & SK17 & SK18 & SK19 & SK22 & & SK23 & SK24 & SK28 & SK35 & SK40 \\
\hline Ulminite & 0 & 80.3 & 83.4 & 51.7 & 93 & 86 & & 0 & 0 & 78.4 & 1 & 70.9 \\
\hline Textinite & 0 & 2.3 & 0 & 1.7 & 0 & 4.3 & & 0 & 0 & 0 & 0 & 5 \\
\hline Densinite & 0 & 0 & 0 & 3.6 & 1.7 & 0 & & 0 & 0 & 2 & 0 & 0 \\
\hline Corpohuminite & 0 & 7.6 & 2.7 & 4.4 & 2.3 & 2.1 & & 0 & 0 & 2.9 & 0 & 6.7 \\
\hline Attrinite & 0 & 0 & 0 & 0 & 0 & 0 & & 0 & 0 & 0 & 0 & 0 \\
\hline HUMINITE & 0 & 90.2 & 86.1 & 61.4 & 97 & 92.4 & & 0 & 0 & 83.3 & 1 & 82.6 \\
\hline Sporinite & 0 & 0 & 0.8 & 5.3 & 0 & 0 & & 0 & 0 & 0 & 0.5 & 0 \\
\hline Suberinite & 0 & 0.7 & 1.1 & 3.6 & 0 & 0 & & 0 & 0 & 0.5 & 0 & 0 \\
\hline Resinite & 0 & 6.1 & 7.3 & 5.3 & 1.5 & 5.4 & & 0 & 0 & 11.2 & 0 & 9 \\
\hline Liptodetrinite & 0 & 0 & 0.8 & 4.3 & 0 & 0 & & 0 & 0 & 1 & 0 & 0 \\
\hline Cutinite & 0 & 0.7 & 0.4 & 0.8 & 0 & 0 & & 0 & 0 & 0 & 0 & 0 \\
\hline LIPTINITE & 0 & 7.5 & 10.4 & 19.3 & 1.5 & 5.4 & & 0 & 0 & 12.7 & 0.5 & 9 \\
\hline Fusinite & 0 & 0 & 0 & 0.9 & 0 & 0 & & 1 & 2.3 & 0 & 0 & 0 \\
\hline Semifusinite & 0 & 0 & 0 & 1.8 & 0 & 0 & & 2.3 & 1 & 0 & 0 & 0 \\
\hline Secretinite & 0 & 0 & 0.9 & 0 & 0 & 0 & & 0 & 0 & 0 & 0 & 0 \\
\hline Macrinite & 0 & 0 & 0 & 5.3 & 0 & 0 & & 1.8 & 2.7 & 0 & 0 & 0 \\
\hline Inertodetrinite & 0 & 0 & 0 & 4.3 & 0 & 0 & & 3.2 & 2.6 & 0 & 0 & 0 \\
\hline Funginite & 0 & 0 & 0 & 0 & 0 & 0 & & 0 & 0 & 0 & 0 & 0 \\
\hline INERTINITE & 0 & 0 & 0.9 & 12.3 & 0 & 0 & & 8.3 & 8.9 & 0 & 0 & 0 \\
\hline Clay minerals & 2.4 & 0.7 & 0 & 5.5 & 0 & 1.2 & & 62.9 & 54.4 & 2 & 62.5 & 2.8 \\
\hline Pyrite & 0 & 0.8 & 0.8 & 0 & 0 & 0 & & 0.6 & 0 & 1.1 & 0.5 & 0 \\
\hline Carbonates & 0 & 0 & 0 & 0 & 1 & 0 & & 1.5 & 0 & 0.5 & 17.8 & 1 \\
\hline Limonite & 0 & 0.8 & 0 & 0 & 0 & 0 & & 0 & 0 & 0 & 0 & 0 \\
\hline Quartz & 0 & 0 & 0 & 0 & 0 & 0 & & 3.2 & 4.4 & 0 & 0 & 0 \\
\hline Others & 3.1 & 0 & 1.8 & 1.5 & 0.5 & 1 & & 10.2 & 7 & 0.4 & 14.7 & 4.6 \\
\hline MINERALS & 5.5 & 2.3 & 2.6 & 7 & 1.5 & 2.2 & & 78.4 & 65.8 & 4 & 95.5 & 8.4 \\
\hline ALTERATION [vol.\%] & 0 & 0 & 0 & 0 & 0 & 0 & & 10.1 & 25.3 & 0 & 3 & 0 \\
\hline CHAR [vol.\%] & 94.5 & 0 & 0 & 0 & 0 & 0 & & 3.2 & 0 & 0 & 0 & 0 \\
\hline
\end{tabular}

The correlation between mean ulminite reflectance and volatile matter (Fig. 4D) displays a considerable amount of scatter within the studied series, especially in samples SK01B, SK01C, SK08 and SK40 with elevated volatile matter content. The observed degree of scatter is attributed to the presence of variable amounts of mineral material, rather than the coal rank. Within the studied sample set, the inorganic 



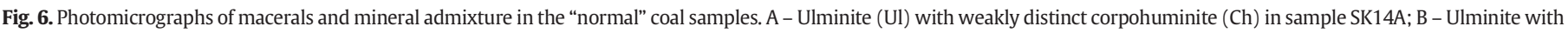

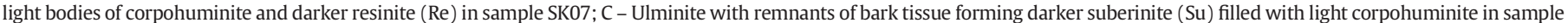

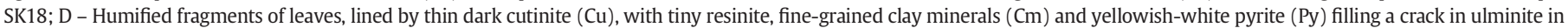

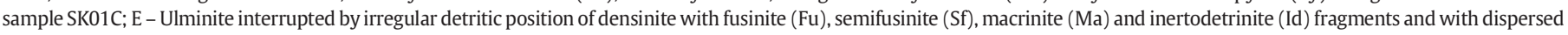

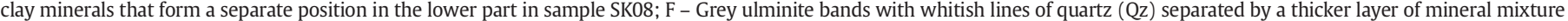
dominated by clay minerals in sample SK01B.

fraction comprises variable proportions of clay minerals and carbonates. Thus, the measured volatile matter content reflects the presence of prevailing minerals rather than the coalification rank (Schobert, 2013).

\subsection{Effect of post-depositional volcanic activity}

Several authors have observed significant changes in coal compositions, especially an increase in thermal maturity, due to igneous intrusions or dykes penetrating coal seams (e.g., Cooper et al., 2007; Dai and Ren, 2007; Rahman and Rimmer, 2014). However, there has been no immediate contact of magma with the coal seams on the Faroe Islands. The basaltic lava flows of the Malinstindur Formation covering the coalbearing Prestfjall Formation were deposited approximately 3-14 m distant from the studied coal seams (Rasmussen and Noe-Nygaard, 1969, 1970), with the upper sequence of volcaniclastic claystone termed the "roof clay", acting as an insulating layer that impedes contact metamorphism and coking of the coal (cf. Chen et al., 2014).

Based on the results of our combined petrological and geochemical approach, we propose two general possibilities for how the coal may have been affected by volcanic effusions: (i) by thermal alteration of limited extent leading to formation of a macroscopically visible, thin "anthracite-like" crust and (ii) by hydrothermal fluids that accompanied volcanic activity.

On the Faroe Islands it is possible to observe coals with an "anthracite-like" degree of coalification (bright, hard and lustrous). Nevertheless, both the petrographic and geochemical analyses argue against the presence of this higher quality coal lithotype. The observed macroscopic appearance of the coal is caused by the presence of a very thin "anthracite-like" surface (Fig. 3C), which may reflect slight thermal alteration, but without an increase in the mean ulminite reflectance. Aghaei et al. (2015) observed an exponential increase of the reflectance 

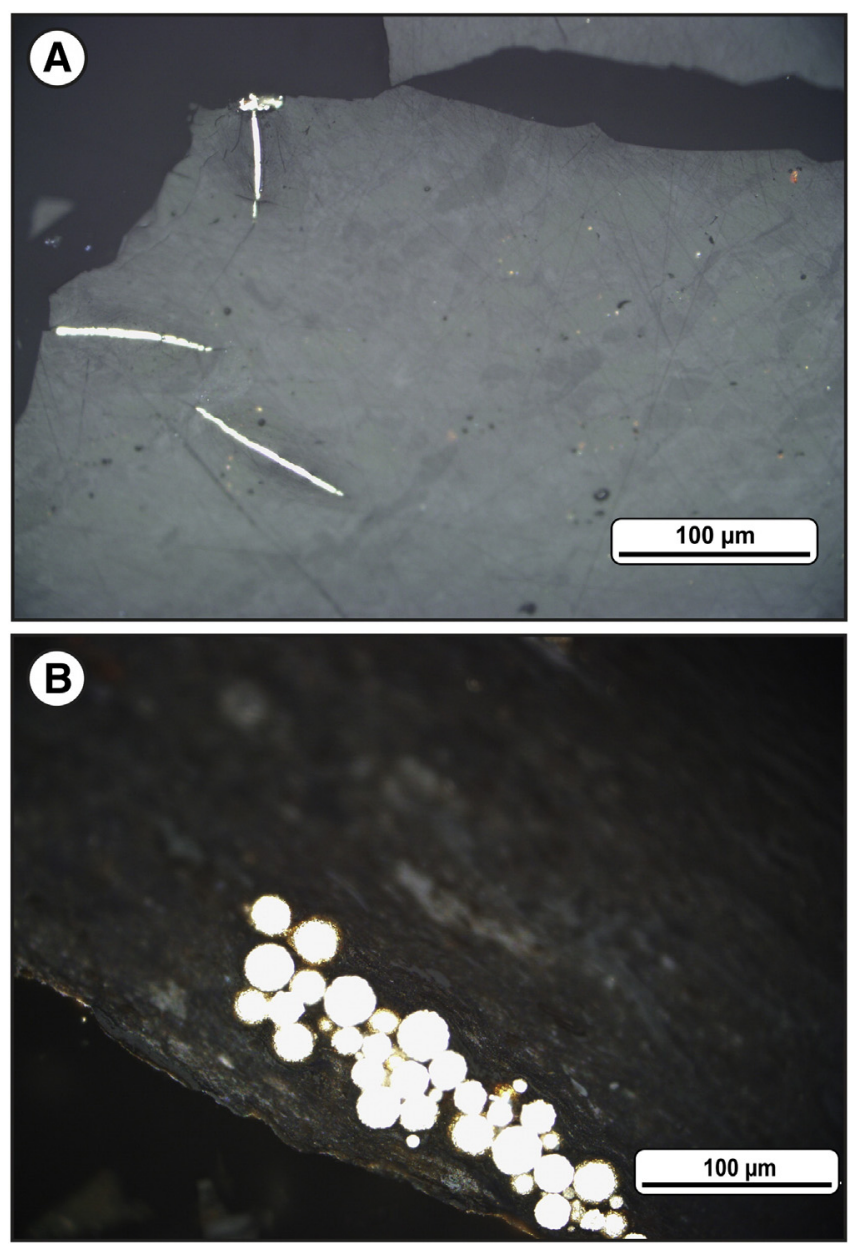

Fig. 7. Photomicrographs of pyrite occurrences in the coal. A - Epigenetic pyrite filling fractures in ulminite in sample SK19. B - Syngenetic pyrite forming a framboid cluster in sample SK09.

directly at the contact of the dyke to the coal seam. At a distance $>2 \mathrm{~m}$ from the dyke contact, only the low initial reflectance values were recorded. The size of the contact aureole is approximately one to two times the thickness of the magmatic body (e.g., Bostick and Pawlewicz, 1984; Crelling and Dutcher, 1968; Galushkin, 1997). Considering the planar character and low viscosity of the basaltic lava, this explains why the rank of the Faroese coal is not elevated.

In contrast, the quality of the coal may have been negatively affected by accompanying hydrothermal mineralization along fractures or faults (Figs. 3A, 9D). According to Gamson et al. (1996), mineralization fills microfractures in compact bright coal of low porosity and permeability, whereas in dull coal of higher porosity and permeability, such as in the "altered organic matter", mineralization can disperse throughout the organic matrix or infill the cell lumens of corpohuminite. Additionally, "altered organic matter" contains inorganic component dominated by clay minerals (Table 3 ). These minerals are very likely a product of hydrothermal decomposition of plagioclase, which is visible both in basalts and in surrounding feldspar-rich tuffitic claystones (Fig. 9A, C, D).

The effect of the basaltic lava flows covering the coal-bearing volcanosedimentary sequences is also recorded in the chemical composition of the "altered organic matter" (cf. Finkelman et al., 1998). Apart from the organic components, the samples consist mainly of clay minerals and carbonates, especially siderite. Dai et al. (2012b) reported possible formation of illite from kaolinite exposed to heat from an igneous body. Dai and Ren (2007) assigned groups of elements with an enrichment trend to thermally altered coal. In accordance with their study, the studied samples of "altered organic matter" are enriched especially in $\mathrm{Cu}$ and $\mathrm{Ni}, \mathrm{Sr}, \mathrm{Zn}, \mathrm{Mn}$ (specifically $\mathrm{MnO}$ ) and less in As, indicating that basaltic lava was the source of these elements. Additionally, the enrichment in V and depletion in $\mathrm{U}$ in the "altered organic matter" is not consistent with their observations. The affinity with basaltic lava is clearly visible from the enrichment in $\mathrm{Ni}$ and $\mathrm{Cr}$. These transition metals are primary characteristics for mantle-derived (basaltic) rocks (e.g., McDonough and Sun, 1995). Our unpublished analyses from overlying basalts (Malinstindur Formation) yield $\mathrm{Ni}$ and $\mathrm{Cr}$ concentrations of 78 ppm and 191 ppm, respectively. These values are relatively low compared to concentrations in primitive plateau basalts of the North Atlantic Igneous Province (cf. Hughes et al., 2015 and references therein) and point to a decomposition of primary mineral phases, i.e., olivine and $\mathrm{Cr}$ rich spinel (Fig. 9A). Transition metals could be released from primary mineral phases and accumulated at nearby geochemical barriers, such as coal seams.

\subsection{Quality of the exploited coal}

A clear correlation between the fuel ratio and the gross calorific value (Fig. 4C) shows that the better combustion suitability and generally greater ease of ignition is attributed to the coal having fewer mineral components. Five samples, namely SK01B, SK01C, SK08, SK19 and SK40 with higher proportions of mineral matter plot in a lower position than samples with lower mineral contents. The "altered organic matter" is entirely unsuitable for combustion because of its very low fuel ratio and gross calorific value, except for the charcoal, which has by contrast the highest fuel ratio, along with an intermediate gross calorific value that is still lower than most of the studied coals.

Despite the macroscopic "anthracite-like" character of the coal from the active New Prestfjall mine ( samples SK01A-C), the coal contains approximately 10 vol.\% of minerals with relatively low carbon content and gross calorific value compared to samples from the abandoned coal mines in the Prestfjall Formation (Table 2). In other words, the coal from the New Prestfjall mine is less suitable for combustion compared to coals mined in the past. Øster-Mortensen (2002) described the coal exploited in the Rókhagi mine (closed in 2013) as coal of high quality, which is in line with our present study.

Coal from the Beinisvørð Formation (Mykines Island) had been extracted locally in small amounts for household use only (Rasmussen and Noe-Nygaard, 1970). This coal is of relatively low rank and quality, although it is older than the higher quality coal from the Prestfjall Formation. The low rank of the coal is indicative of very fast coalification due to the short duration of sedimentation and subsequent burial by basalts (cf. Dvořák et al., 1997). Lower coal rank was produced by mineralizing fluids that migrated along a fault and filled corpohuminite cells in the coal (Fig. 3A).

\subsection{Coal geochemistry}

The low sulphur contents $(<1 \%)$ of the Faroese coal are primarily of organic origin, i.e., they derive from coal-forming plants (Chou, 2012) and to a lesser extent, correlate with small amounts of pyrite occurring both in epigenetic and syngenetic form as fracture fillings and framboids, respectively (Fig. 7A, B). The organic sulphur is mainly associated with vitrinite (or ulminite in low-rank coal), suggesting a positive correlation with the gelification degree (Dai et al., 2002).

Major oxides are dominated by $\mathrm{SiO}_{2}, \mathrm{Al}_{2} \mathrm{O}_{3}$ and $\mathrm{Fe}_{2} \mathrm{O}_{3}$, corresponding to a mineral assemblage of clay minerals, quartz, pyrite, siderite and limonite. Limonite occurs exclusively on the surface of some samples in very small amounts. In case of its presence, it never replaces pyrite completely. Along with the microscopic appearance of pyrite (see Fig. 7A, B), this is indicative of freshness of studied samples (Littke et al., 1991). Compared to coal from the Prestfjall Formation, the "normal" coal sample from the Beinisvørð Formation is relatively enriched in trace elements, namely $\mathrm{Rb}, \mathrm{Sr}, \mathrm{W}$ and $\mathrm{Ni}$. Whereas the coal seams in the Prestfjall Formation are up to $1.5 \mathrm{~m}$ thick, the lenses sampled in 

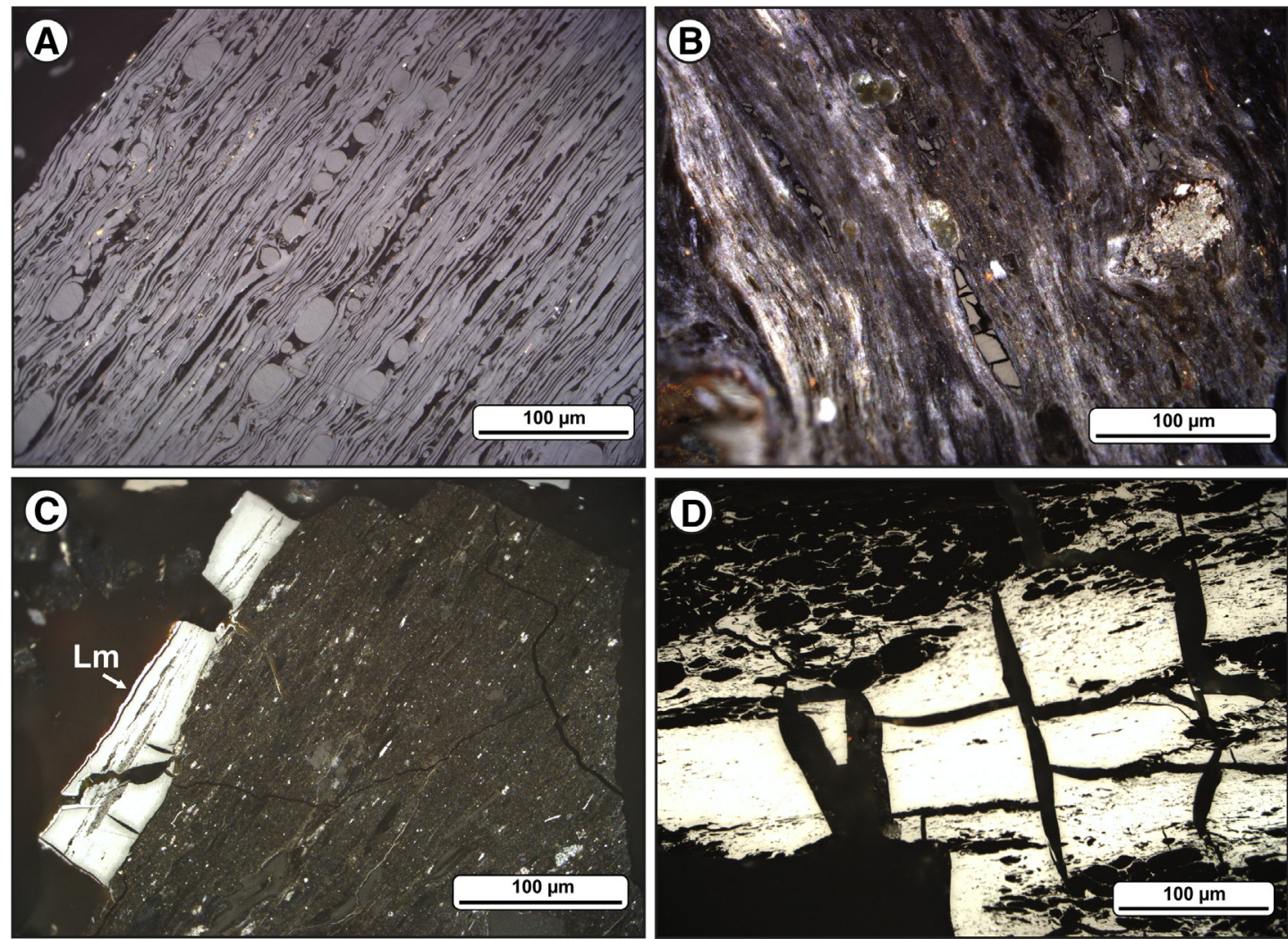

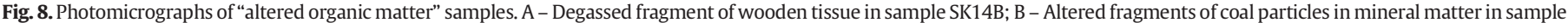

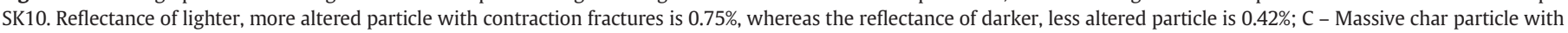

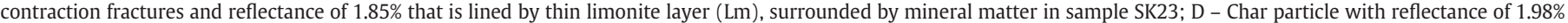
measured on the massive centre that is interrupted by distinct contraction fractures and rimmed by mosaic texture in sample SK23.

the Beinisvørð Formation are only a few centimetres thick. Some previous studies discuss the relationship between enrichment of certain trace elements and thickness of the coal seams (e.g., Chen et al., 2015; Eskenazy and Valceva, 2003; Li et al., 2012; Querol et al., 1992; Van Krevelen, 1963). Van Krevelen (1963) noted that thin coal layers are usually enriched in some trace elements compared to thick ones. According to Querol et al. (1992), this behaviour is related to postdepositional epigenetic percolation of diagenetic fluids through a

Table 4

Reflectance of ulminite B, altered particles and char.

\begin{tabular}{|c|c|c|c|c|c|}
\hline Sample ID & Coal type & $\mathbf{R}_{\mathbf{r}}$ [\%] & $\sigma$ & $\mathbf{R}_{\text {alt }}[\%]$ & $\mathbf{R}_{\text {char }}[\%]$ \\
\hline SK01A & xylite & 0.46 & 0.05 & - & - \\
\hline SK01B & detroxylite & 0.41 & 0.05 & - & - \\
\hline SK01C & detroxylite & 0.42 & 0.05 & 0.56 & - \\
\hline SK04 & detroxylite & 0.40 & 0.05 & - & - \\
\hline SK06 & xylite & 0.45 & 0.04 & - & - \\
\hline SK07 & detroxylite & 0.46 & 0.06 & 0.58 & - \\
\hline SK08 & detroxylite & 0.53 & 0.06 & 0.67 & - \\
\hline SK09 & detroxylite & 0.45 & 0.08 & - & - \\
\hline SK10 & mineral-rich & 0.42 & 0.10 & 0.93 & - \\
\hline SK12 & detroxylite & 0.47 & 0.06 & - & - \\
\hline SK13 & detroxylite & 0.44 & 0.08 & - & - \\
\hline SK14A & xylite & 0.42 & 0.07 & - & - \\
\hline SK14B & charcoal & - & - & - & 0.87 \\
\hline SK16 & xylite & 0.48 & 0.05 & - & - \\
\hline SK17 & xylite & 0.41 & 0.07 & - & - \\
\hline SK18 & detroxylite & 0.43 & 0.09 & - & - \\
\hline SK19 & xylite & 0.40 & 0.04 & - & - \\
\hline SK22 & xylite & 0.39 & 0.05 & - & - \\
\hline SK23 & mineral-rich & - & - & 0.56 & 1.93 \\
\hline SK24 & mineral-rich & - & - & 0.83 & - \\
\hline SK28 & detroxylite & 0.45 & 0.08 & - & - \\
\hline SK35 & mineral-rich & 0.39 & 0.05 & 1.35 & - \\
\hline SK40 & xylite & 0.34 & 0.04 & - & - \\
\hline
\end{tabular}

fracture network, which was previously better developed in thinner seams than in thicker ones. Thus, the low thicknesses could explain why coal from the Beinisvørð Formation is more enriched in the trace elements listed above than coal from the Prestfjall Formation.

\subsection{Mercury speciation, behaviour and environmental impact}

Trace $\mathrm{Hg}$ analysis revealed that mercury contents in the Faroese coal are generally low. Similar or slightly higher concentrations were also reported from Palaeozoic bituminous coals from the Czech Republic (Coufalík et al., 2011). This observation supports the idea that no correlation exists between mercury content and coal rank (Kilgroe et al., 2002).

Additionally, all studied samples are classified as low-sulphur coals (Chou, 2012). As described by Yudovich and Ketris (2005a), lowsulphur coals that are generally poor in $\mathrm{Hg}$ are dominated by only two $\mathrm{Hg}$ forms: $\mathrm{Hg}_{\text {org }}$ (mercury bound to humic substances) and $\mathrm{Hg}_{\text {sulphide }}$ (commonly pyritic mercury, $\mathrm{Hg}_{\text {pyr }}$ ). In addition to $\mathrm{Hg}$ and $\mathrm{S}$, our samples were characterized by low As contents. The data indicate relatively low amounts of $\mathrm{Hg}_{\mathrm{pyr}}$ in the coal (Kolker et al., 2006).

The $\mathrm{CAI}_{\mathrm{Hg}}$ ( $\mathrm{Hg}$ coal affinity index) is between 0.3 and 4.2 for "normal" coal samples. In comparison, "altered organic matter" samples show only limited $\mathrm{CAI}_{\mathrm{Hg}}$ values of $\sim 0.1$. Values of $\mathrm{CAI}_{\mathrm{Hg}}>1$ indicate that the studied coal does not act as a geochemical barrier for the mercury, suggesting that alteration processes resulted in removal of the mercury from the affected coal seam to the surrounding sediments.

The finding that "altered organic matter" contains less mercury than "normal" coal could be related to volcanic activity. The solubility of $\mathrm{Hg}$ species increases with higher temperatures produced by adjacent volcanic effusions. The mercury becomes mobile and can be more easily leached from organic matter by hydrothermal fluids 

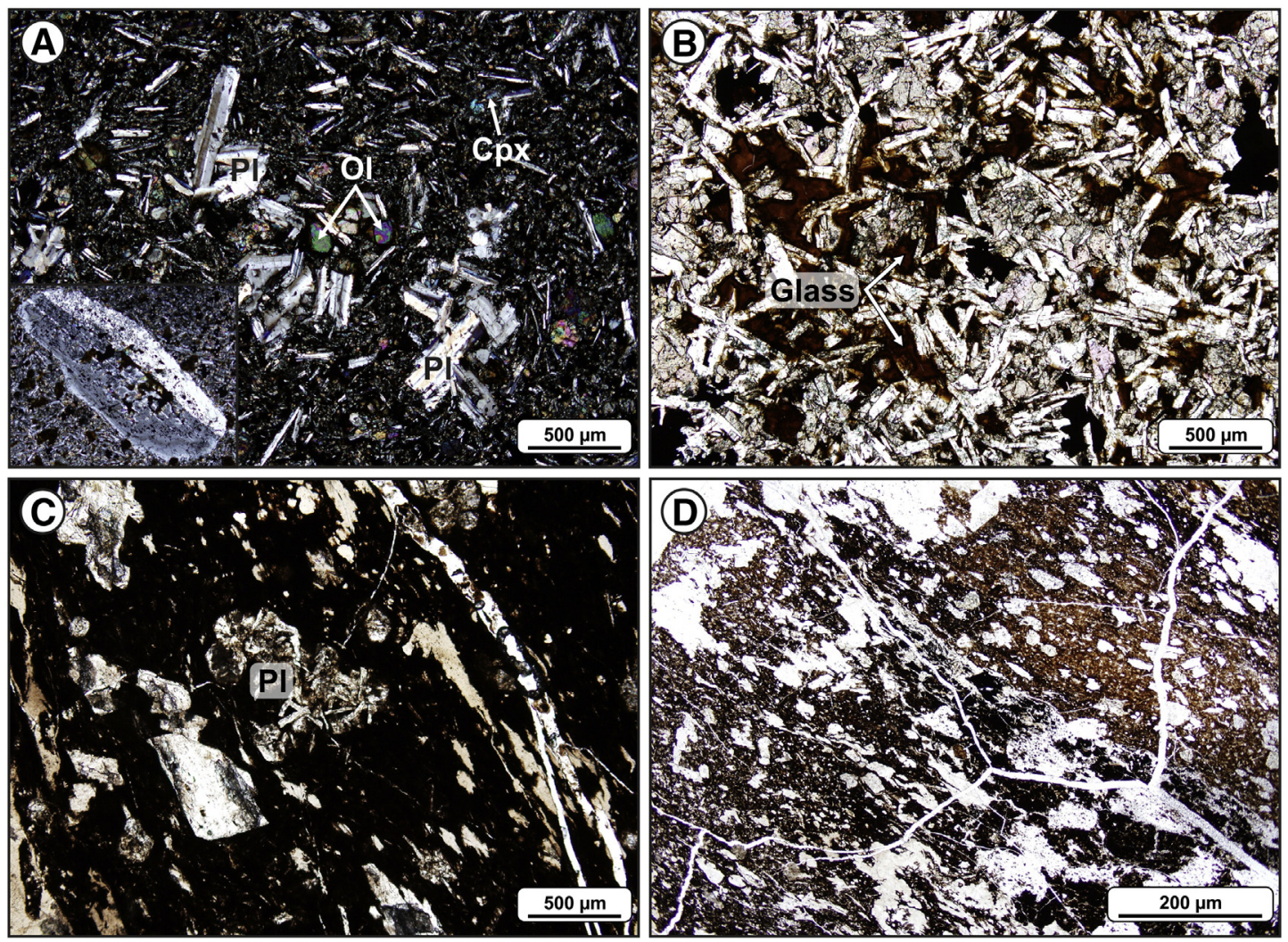

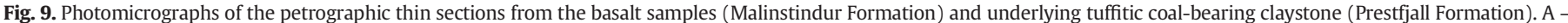

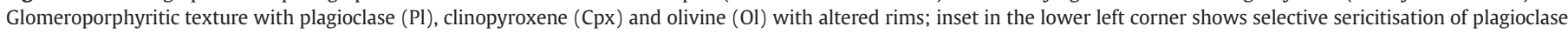

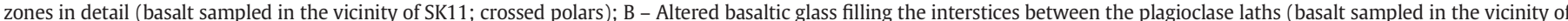

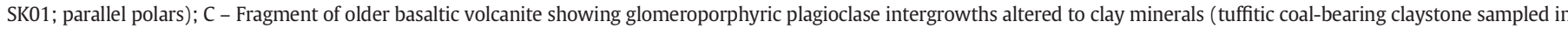

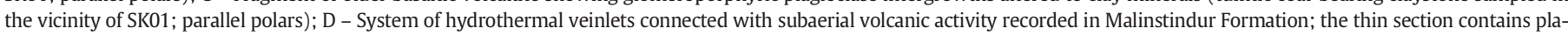
gioclase pseudomorphosis filled by products of its alteration (tuffitic coal-bearing claystone sampled in the vicinity of SK01; parallel polars).

(Fein and Williams-Jones, 1997; Moiseyev, 1971; Peabody and Einaudi, 1992). Finkelman et al. (1998) found that mercury content is higher in close proximity to an intrusive body due to secondary

Table 5

Contents of major oxides in the samples from the Faroe Islands (wt.\%; on a whole-coal basis).

\begin{tabular}{lcccccccc}
\hline Sample ID & $\mathbf{S i O}_{\mathbf{2}}$ & $\mathbf{T i O}_{\mathbf{2}}$ & $\mathbf{A l}_{\mathbf{2}} \mathbf{O}_{\mathbf{3}}$ & $\mathbf{F e}_{\mathbf{2}} \mathbf{O}_{\mathbf{3}}^{\text {tot }}$ & $\mathbf{M n O}$ & $\mathbf{C a O}$ & $\mathbf{K}_{\mathbf{2}} \mathbf{0}$ & $\mathbf{P}_{\mathbf{2}} \mathbf{O}_{\mathbf{5}}$ \\
\hline SK01A & 1.54 & $\mathrm{BDL}$ & 1.11 & 0.75 & 0.002 & 1.39 & 0.06 & $\mathrm{BDL}$ \\
SK01B & 1.59 & $\mathrm{BDL}$ & 1.16 & 0.36 & 0.002 & 0.41 & 0.07 & $\mathrm{BDL}$ \\
SK01C & 3.95 & 0.29 & 3.11 & 5.05 & 0.009 & 1.11 & 0.04 & 0.03 \\
SK04 & 7.57 & 0.38 & 7.10 & 0.82 & 0.001 & 1.69 & $\mathrm{BDL}$ & $\mathrm{BDL}$ \\
SK06 & 8.59 & 0.88 & 7.22 & 0.85 & 0.013 & 1.24 & $\mathrm{BDL}$ & 0.04 \\
SK07 & 2.36 & $\mathrm{BDL}$ & 1.74 & 0.38 & $\mathrm{BDL}$ & 3.51 & 0.04 & $\mathrm{BDL}$ \\
SK08 & 5.86 & 1.03 & 5.59 & 3.27 & 0.011 & 1.44 & $\mathrm{BDL}$ & 0.18 \\
SK09 & 2.15 & $\mathrm{BDL}$ & 1.70 & 0.47 & 0.013 & 0.90 & 0.06 & $\mathrm{BDL}$ \\
SK10 & 26.25 & 4.13 & 19.91 & 3.60 & 2.877 & 0.03 & $\mathrm{BDL}$ & 0.06 \\
SK12 & 1.92 & $\mathrm{BDL}$ & 1.71 & 0.66 & 0.003 & 3.09 & 0.04 & 0.04 \\
SK13 & 6.98 & 0.61 & 6.39 & 2.12 & 0.004 & 1.49 & $\mathrm{BDL}$ & 0.05 \\
SK14A & 1.93 & $\mathrm{BDL}$ & 1.70 & 1.27 & $\mathrm{BDL}$ & 5.11 & $\mathrm{BDL}$ & 0.03 \\
SK14B & 4.38 & $\mathrm{BDL}$ & 2.12 & 0.31 & $\mathrm{BDL}$ & 0.51 & 0.06 & 0.04 \\
SK16 & 2.87 & $\mathrm{BDL}$ & 2.41 & 0.40 & $\mathrm{BDL}$ & 2.09 & 0.03 & 0.01 \\
SK17 & 2.46 & $\mathrm{BDL}$ & 2.66 & 0.44 & $\mathrm{BDL}$ & 1.05 & 0.06 & 0.04 \\
SK18 & 8.47 & 0.39 & 8.44 & 1.23 & 0.01 & 1.58 & $\mathrm{BDL}$ & 0.02 \\
SK19 & 0.92 & $\mathrm{BDL}$ & 0.85 & 0.44 & $\mathrm{BDL}$ & 0.86 & 0.04 & 0.01 \\
SK22 & 3.40 & 0.01 & 3.83 & 0.86 & 0.002 & 2.91 & 0.01 & 0.02 \\
SK23 & 37.13 & 2.15 & 25.14 & 4.43 & 0.472 & 0.06 & $\mathrm{BDL}$ & 0.22 \\
SK24 & 1.06 & $\mathrm{BDL}$ & 1.26 & 0.75 & $\mathrm{BDL}$ & 1.43 & 0.11 & 0.03 \\
SK28 & 2.72 & 0.05 & 3.15 & 0.76 & 0.017 & 2.22 & 0.09 & 0.10 \\
SK35 & 30.14 & 2.09 & 12.50 & 16.13 & 0.096 & 1.34 & 0.16 & 0.07 \\
SK40 & 7.82 & 0.03 & 2.31 & 1.26 & 0.017 & 2.97 & 0.15 & 0.40 \\
\hline $\mathrm{BDL}-\mathrm{b}$ & & & & & & & & \\
\hline
\end{tabular}

BDL - below detection limit enrichment following volatilization of $\mathrm{Hg}$ during heat exposure and its subsequent redeposition from fluids derived from the cooling magma. No traces of mercury were recorded at a distance $>50 \mathrm{~cm}$ from the intrusion.

In low-rank coal, such as that in the Faroese samples, the extent of mercury removal is much lower compared to bituminous coal (Kilgroe et al., 2002). Combined with the low levels of $\mathrm{Hg}$ in the coal, its combustion has only a limted impact on the environment.

\subsection{Depositional environment of Faroese coal}

\subsubsection{Maceral composition}

In accordance with the studies of Diessel (1992) and Teichmüller (1989), the occurrence of ulminite, corpohuminite, fusinite and semifusinite with associated resinite or suberinite point to a forest habitat, whereas the presence of densinite, liptodetrinite and inertodetrinite denote inputs of herbaceous vegetation. The strong gelification of huminite macerals reflects mostly wet conditions in a peat-forming swamp. Significant variability of the liptodetrinite and sporinite assemblages suggests unstable conditions due to a fluctuating water table (Kolcon and Sachsenhofer, 1999). The absence of alginite in coal is incompatible with marine inputs to the depositional environment of the Faroese coal. The coal plots at Apex A in the maceral-based ternary diagram of Mukhopadhyay (1989), later modified for low-rank coal by Singh et al. (2010) and is indicative of swamp vegetation with preserved cell structures that have been coalified in variably anoxic and oxic conditions (Fig. 11).

In the fusitic charcoal-rich sample SK14B, charred matter of textinite, specifically fusinite and semifusinite, predominates. It is assumed that this type of coal was derived from wood affected by local 


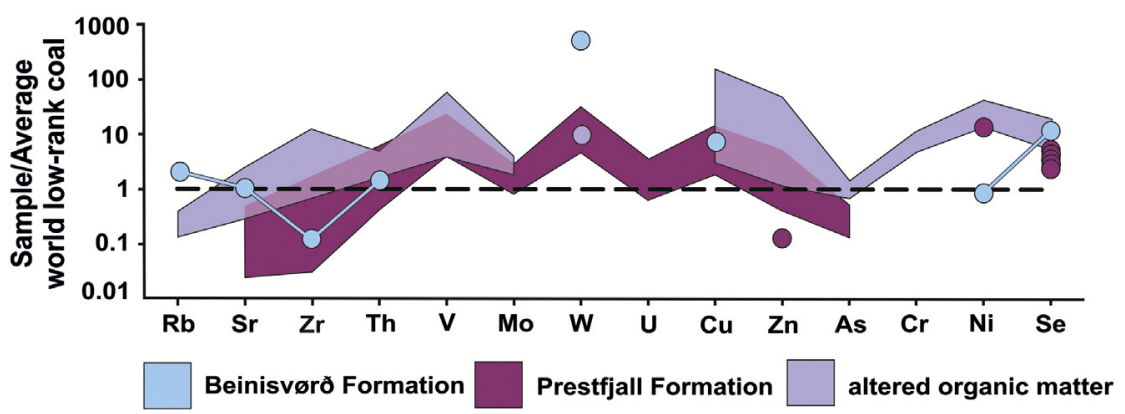

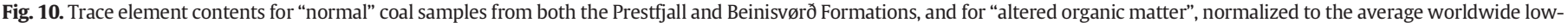
rank coal composition (Ketris and Yudovich, 2009). Circles express individual analyses or analyses that do not fit the range for a given sample type.

wildfires, weathering or microbial activity (Cohen and Spackman, 1977; Cope and Chaloner, 1985; ICCP, 2001; Scott, 2002) or it may be formed from wood remnants affected by heat from the lava flow. The latter would explain the variable development of this sample compared to the other studied coals.

Table 6

Concentrations of trace elements in the samples from the Faroe Islands (ppm; on a wholecoal basis).

\begin{tabular}{|c|c|c|c|c|c|c|c|c|}
\hline Sample ID & $\mathbf{V}$ & $\mathrm{Cr}$ & $\mathrm{Ni}$ & $\mathrm{Cu}$ & $\mathrm{Zn}$ & As & Se & $\mathbf{R b}$ \\
\hline SK01A & $\mathrm{BDL}$ & $\mathrm{BDL}$ & $\mathrm{BDL}$ & $\mathrm{BDL}$ & 16 & BDL & BDL & BDL \\
\hline SK01B & BDL & $\mathrm{BDL}$ & BDL & BDL & BDL & BDL & BDL & BDL \\
\hline SK01C & 285 & BDL & BDL & 78 & 58 & 1.7 & 6.4 & BDL \\
\hline SK04 & 413 & $\mathrm{BDL}$ & $\mathrm{BDL}$ & BDL & 33 & 3.2 & BDL & BDL \\
\hline SK06 & 254 & $\mathrm{BDL}$ & BDL & 118 & 31 & $\mathrm{BDL}$ & $\mathrm{BDL}$ & BDL \\
\hline SK07 & BDL & $\mathrm{BDL}$ & BDL & BDL & BDL & 1.8 & BDL & BDL \\
\hline SK08 & 242 & $\mathrm{BDL}$ & BDL & 179 & 64 & 1.2 & 4.3 & BDL \\
\hline SK09 & BDL & $\mathrm{BDL}$ & BDL & BDL & BDL & BDL & BDL & BDL \\
\hline SK10 & 768 & 126 & 159 & 1736 & 101 & 6.8 & 6.8 & 1.8 \\
\hline SK12 & BDL & BDL & BDL & 33 & 27 & 1.4 & BDL & BDL \\
\hline SK13 & 97 & $\mathrm{BDL}$ & BDL & 34 & 15 & BDL & 7.0 & BDL \\
\hline SK14A & BDL & $\mathrm{BDL}$ & BDL & 119 & 8.6 & BDL & BDL & BDL \\
\hline SK14B & BDL & $\mathrm{BDL}$ & BDL & $\mathrm{BDL}$ & 9.1 & BDL & 2.8 & BDL \\
\hline SK16 & BDL & $\mathrm{BDL}$ & BDL & $\mathrm{BDL}$ & 2.7 & $\mathrm{BDL}$ & BDL & BDL \\
\hline SK17 & $\mathrm{BDL}$ & $\mathrm{BDL}$ & BDL & BDL & BDL & BDL & BDL & BDL \\
\hline SK18 & 252.51 & $\mathrm{BDL}$ & BDL & 118.65 & 31.02 & $\mathrm{BDL}$ & 5.16 & BDL \\
\hline SK19 & BDL & $\mathrm{BDL}$ & BDL & BDL & BDL & $\mathrm{BDL}$ & BDL & BDL \\
\hline SK22 & 393.36 & BDL & BDL & BDL & 39.7 & BDL & BDL & BDL \\
\hline SK23 & 987 & 89.3 & 291 & 1229 & 663 & 6.8 & 14.7 & 1.9 \\
\hline SK24 & BDL & BDL & BDL & BDL & BDL & BDL & BDL & BDL \\
\hline SK28 & 352 & $\mathrm{BDL}$ & 140 & 105 & 97 & BDL & BDL & BDL \\
\hline SK35 & 517 & 45 & 80 & 1304 & 128 & 10 & 5.3 & 12 \\
\hline SK40 & BDL & BDL & 7.4 & 108 & BDL & BDL & 9.7 & 18 \\
\hline Sample ID & $\mathrm{Sr}$ & & $\mathrm{Zr}$ & Mo & $\mathbf{w}$ & & Th & $\mathbf{U}$ \\
\hline SK01A & 9.2 & & 4.6 & BDL & 6.6 & & 3.5 & BDL \\
\hline SK01B & 6.3 & & 3.9 & BDL & BDL & & 5.9 & 2.5 \\
\hline SK01C & 20 & & 39 & 2.1 & BDL & & 4.0 & BDL \\
\hline SK04 & 7.1 & & 9.1 & BDL & 19 & & BDL & BDL \\
\hline SK06 & 7.2 & & 15 & BDL & BDL & & BDL & BDL \\
\hline SK07 & 11 & & 6.6 & 6.5 & 10 & & 10.7 & 2.8 \\
\hline SK08 & 57 & & 51 & BDL & BDL & & BDL & BDL \\
\hline SK09 & 37 & & 3.4 & BDL & BDL & & 6.9 & 4.7 \\
\hline SK10 & 223 & & 309 & 6.5 & BDL & & 12 & BDL \\
\hline SK12 & 7.9 & & 8.4 & 5.0 & 13 & & 15 & 5.3 \\
\hline SK13 & 5.6 & & 33 & BDL & BDL & & BDL & BDL \\
\hline SK14A & 15 & & 1.3 & BDL & BDL & & 2.0 & BDL \\
\hline SK14B & 4.3 & & 9.5 & 5.5 & 20 & & 17 & 8.5 \\
\hline SK16 & 9.5 & & 1.8 & BDL & BDL & & 3.2 & BDL \\
\hline SK17 & 8.12 & & BDL & BDL & BDL & & 1.65 & BDL \\
\hline SK18 & 15.56 & & 36.75 & BDL & BDL & & BDL & BDL \\
\hline SK19 & 3.5 & & 3.8 & BDL & BDL & & 6.1 & 2.2 \\
\hline SK22 & 5.1 & & 3.2 & BDL & 31.73 & & BDL & BDL \\
\hline SK23 & 93 & & 339 & 5.2 & BDL & & 11 & BDL \\
\hline SK24 & 20 & & 4.1 & BDL & BDL & & 4.0 & 2.7 \\
\hline SK28 & 8.2 & & 3.05 & BDL & 27 & & BDL & BDL \\
\hline SK35 & 104 & & 165 & 8.8 & BDL & & 6.4 & BDL \\
\hline SK40 & 120 & & 4.4 & BDL & 606 & & 4.8 & BDL \\
\hline
\end{tabular}

Apart from the "altered organic matter", small amounts of detrital minerals dispersed throughout the organic matter of the "normal" coal were observed. These may result from intermittent flooding or a fluctuating lake level, as proposed for the studied area by Passey (2014).

\subsubsection{Relationship between sulphur contents and the depositional} environment

Coal from the Faroe Islands contains $0.03-0.99 \%$ sulphur and is therefore classified as a low-sulphur coal (Chou, 2012). Sulphur abundances $<1 \%$ generally suggest low-pH conditions in the swamp (Bechtel et al., 2003). Occurrences of framboidal pyrite may be related to freshwater inputs resulting in more reducing conditions that are conductive to reducing bacteria (Strobl et al., 2014). Some authors suggest that higher proportions of the sulphur may be related to marine inputs, whereas low-sulphur coals are commonly deposited in continental environments (e.g., Chou, 2012; Dai and Ren, 2007; Markič and Sachsenhofer, 1997). However, a non-marine high-sulphur Miocene lignite with a sulphur content of up to $12.2 \%$ was reported in Turkey by Gürdal (2011) and Gürdal and Bozcu (2011), who suggested that high sulphur abundance in the lignite can be attributed to regional volcanic activity. Additionally, Dai et al. (2012a) observed an assemblage of syngenetic pyrite in non-marine medium-sulphur coal that was probably derived from sulphate-rich epithermal solutions. Considering the low sulphur contents in studied samples from the Faroe Islands, it is possible to exclude the influence of seawater during peat accumulation.

\subsubsection{Comparison with results from palynological studies}

Palynological studies of the Faroese coal and adjacent sediments were performed by Ellis et al. (2002) and Lund (1989) for both Suðuroy and Mykines Island. The palynoflora is dominated by Inaperturopollenites hiatus, Caryapollenites circulus, $C$. veripites, $C$. triangulus, Laevigatosporites haardtii, Monocolpopollenites tranquilus, Momipites, Pityosporites spp. and sporadically occurring Phaseoidites stanleyii, Striatricolporites sp. and Montanapollis spp. This tree association is typical for deposition in a warm humid climate within extensive peat swamps on overbank floodplains or small lakes margins (Wing and Hickey, 1984). No

Table 7

Mercury abundances in representative samples from studied localities.

\begin{tabular}{lcccccc}
\hline $\begin{array}{l}\text { Sample } \\
\text { ID }\end{array}$ & Formation & Locality & Sample type & $\begin{array}{c}\text { Hg } \\
\text { [ppb] }\end{array}$ & $\begin{array}{c}\text { RSD } \\
\text { [\%] }\end{array}$ & CAI $_{\mathbf{H g}}$ \\
\hline SK01B & Prestfjall & New Prestfjall mine & detroxylite & 56 & 1.06 & 1.12 \\
SK04 & Prestfjall & Kolaminur & detroxylite & 22 & 2.39 & 0.44 \\
SK12 & Prestfjall & Rókhagi & detroxylite & 127 & 2.99 & 2.54 \\
SK16 & Prestfjall & Rangibotnur & xylite & 35 & 2.05 & 0.7 \\
SK22 & Prestfjall & Gudmund's mine & xylite & 210 & 1.93 & 4.2 \\
SK24 & Prestfjall & Kolavegurin & mineral-rich & 9 & 0.52 & 0.18 \\
SK40 & Beinisvørð & Mykines & xylite & 14 & 1.97 & 0.28 \\
\hline
\end{tabular}

RSD - relative standard deviation

$\mathrm{CAI}_{\mathrm{Hg}}-\mathrm{Hg}$ coal affinity index 


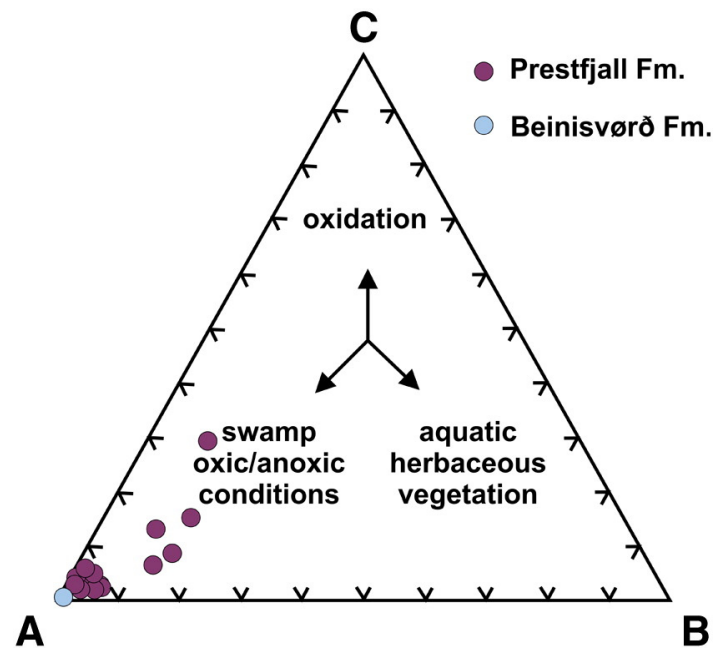

Fig. 11. ABC ternary diagram of the Faroese coal samples modified after Mukhopadhyay (1989). A

ulminite + textinite + corpohuminite + sporinite + cutinite + resinite + suberinite; $\mathrm{B}-$ densinite + attrinite + liptodetrinite; $\mathrm{C}$ - inertinite. The "altered organic matter" samples were not included in this diagram due to their irrelevance in assessment of depositional environment.

marine flora were observed within the Faroese coal. Additionally, Lund (1989) discovered the presence of fresh water algae, Sigmopollis, in coal from the Rókhagi mine, suggesting a lake environment. The algae were accompanied by Polypodiaceoisporites marxheimensi, indicating that the lake was surrounded by forest swamps. These palynological studies fully support the depositional environment (wet forest swamps in proximity to a lake) suggested in our study for the Faroese coal.

\section{Conclusions}

Based on a combined petrographic and geochemical approach, our study obtanis the following results:

(1) The rank of Palaeogene coal from the Faroe Islands is lignite to subbituminous. The coal is generally characterized by low sulphur contents, medium ash yields and high volatile matter contents.

(2) The maceral composition of the coal is dominated by ulminite with an average mean reflectance of $0.34-0.53 \%$. The proportions of liptinite and inertinite vary in coal samples.

(3) The coal was derived from wood in a wet forest swamp environment in proximity to a lake with possibly fluctuating water levels.

(4) Basalt lava flows of the Malinstindur Formation overlying the coalbearing Prestfjall Formation affected the coal to a limited degree. Thermal effects include only a thin "anthracite-like" crust, with no signs of elevated coal rank. Fluids accompanying the volcanic activity induced decomposition of primary mineral phases in basalts as well as in the surrounding volcaniclastic sediments and enriched the affected coal in mineral components. The low original rank of the coal explains the absence of typical high mean reflectance and natural coke textures throughout the coal sequence.

(5) Coal from the older Beinisvørð Formation can be distinguished from that of the Prestfjall Formation based on petrographic and geochemical criteria. The coal from the Prestfjall Formation is of higher quality and has therefore been mined in many locations on Suðuroy Island. However, only one coal mine is presently in operation and the quality of the mined coal is lower than it was in the past.

(6) Combustion of Faroese coal has a relatively low impact on the local environment due to low $\mathrm{Hg}$, As and $\mathrm{S}$ contents.

\section{Acknowledgements}

Financial support to S.K. and R.P. was provided by the J.E. Purkyně University Internal Grant Agency FŽP IG 1/2014 and by OPVK EnviMod (CZ.1.07/2.2.00/28.0205) project. L.K. was financially supported by project No. RVO67985831 of the Institute of Geology CAS, Prague and by a BUT project No. L01408 "AdMaS UP - Advanced Materials, Structures and Technologies", which is supported by the Ministry of Education, Youth and Sports of the Czech Republic under the "National Sustainability Programme I". The involvement of P.C. was supported by the Institute of Analytical Chemistry of the CAS under the Institutional Research Plan RVO: 68081715. We are indebted to I. Sýkorová and E. Geršlová for their excellent help with descriptions of maceral and elemental compositions. We gratefully acknowledge M. Havelcová (IRSM, CAS, Prague) for performing chemical analyses, which were covered by the Czech Science Foundation (Research Grant No. 13-18482S). Many thanks are also given to M.J. Timmerman (University of Potsdam), R.L. Romer (GFZ Potsdam) and R. Macdonald (Lancaster University) for their corrections and discussion that helped to improve the original manuscript. We sincerely thank to U.E. Árting (The Faroese Earth and Energy Directorate - Jarðfeingi) for providing maps and kind help during field exploration. We greatly appreciate an anonymous reviewer and editor-in-chief R. Littke for their constructive and helpful comments and suggestions.

\section{References}

Aghaei, H., Gurba, L.W., Ward, C.R., Hall, M., Mahmud, S.A., 2015. Effects of igneous intrusions on thermal maturity of carbonaceous fluvial sediments: a case study of the Early Cretaceous Strzelecki Group in west Gippsland, Victoria, Australia. Int. J. Coal Geol. 152, 68-77.

Amijaya, H., Littke, R., 2006. Properties of thermally metamorphosed coal from Tanjung Enim Area, South Sumatra Basin, Indonesia with special reference to the coalification path of macerals. Int. J. Coal Geol. 66, 271-295.

Bechtel, A., Gruber, W., Sachsenhofer, R.F., Gratzer, R., Lücke, A., Püttmann, W., 2003. Depositional environment of the Late Miocene Hausruck lignite (Alpine Foreland Basin): insights from petrography, organic geochemistry, and stable carbon isotopes. Int. J. Coal Geol. 53, 153-180.

Bohnhoff, M., Makris, J., 2004. Crustal structure of the southeastern Iceland-Faeroe Ridge (IFR) from wide aperture seismic data. J. Geodyn. 37, 233-252.

Bostick, N.H., Pawlewicz, M.J., 1984. Paleotemperatures based on vitrinite reflectance of shales and limestones in igneous dike aureoles in the Upper Cretaceous Pierre Shale, Walsenburg, Colorado. In: Woodward, J.G., Meissner, F.F., Clayton, J.L. (Eds.) Hydrocarbon Source Rocks of the Greater Rocky Mountain Region. Rocky Mountain Association of Geologists, Denver, pp. 387-392.

Bott, M.H.P., Sunderland, J., Smith, P.J., 1974. Evidence for continental crust beneath the Faeroe Islands. Nature 248, 202-204.

Bussio, J.P., Roberts, J.R., 2016. A large scale investigation into changes in coal quality caused by dolerite dykes in Secunda, South Africa-implications for the use of proximate analysis on a working mine. J. Afr. Earth Sci. 117, 401-409.

Casten, U., 1973. The crust beneath the Faeroe Islands. Nature 241, 83-84.

Chen, J., Liu, G., Li, H., Wu, B., 2014. Mineralogical and geochemical responses of coal to igneous intrusion in the Pansan Coal Mine of the Huainan coalfield, Anhui, China. Int. J. Coal Geol. 124, 11-35.

Chen, J., Chen, P., Yao, D., Liu, Z., Wu, Y., Liu, W., Hu, Y., 2015. Mineralogy and geochemistry of Late Permian coals from the Donglin Coal Mine in the Nantong coalfield in Chongqing, southwestern China. Int. J. Coal Geol. 149, 24-40.

Chou, C.-L., 2012. Sulfur in coals: a review of geochemistry and origins. Int. J. Coal Geol $100,1-13$

Cohen, A.D., Spackman, W., 1977. Phytogenic organic sediments and sedimentary environments in the Everglades mangrove complex: part II. The origin, description and classification of the peats of southern Florida. Palaeontographica 162B, $71-114$.

Cooper, J.R., Crelling, J.C., Rimmer, S.M., Whittington, A.G., 2007. Coal metamorphism by igneous intrusion in the Raton Basin, $\mathrm{CO}$ and NM: implications for generation of volatiles. Int. J. Coal Geol. 71, 15-27.

Cope, M.J., Chaloner, W.G., 1985. Wildfire: an interaction of biological and physical processes. In: Tiffney, B.H. (Ed.), Geological Factors and the Evolution of Plants. Yale University Press, New Haven, pp. 257-277.

Coufalík, P., Červenka, R., Komárek, J., 2011. Mercury speciation in soil in vicinity of coa beds using sequential extraction. Environ. Earth Sci. 62, 421-427.

Crelling, J.C., Dutcher, R.R., 1968. A petrologic study of a thermally altered coal from the Purgatoire River Valley of Colorado. Geol. Soc. Am. Bull. 79, 1375-1386.

Czech technical standards ČSN 44 1377, 2004. Solid mineral fuels - determination of moisture. Czech office for Standards, Metrology and Testing, Prague (in Czech).

Czech technical standards ČSN ISO 1171, 2001. Solid mineral fuels - determination of ash. Czech office for Standards, Metrology and Testing, Prague (in Czech).

Czech technical standards ČSN ISO 29541, 2012r. Solid mineral fuels - determination of total carbon, hydrogen and nitrogen content - instrumental method. Czech office for Standards, Metrology and Testing, Prague (in Czech). 
Dai, S., Li, W., Tang, Y., Zhang, Y., Feng, P., 2007. The sources, pathway, and preventive measures for fluorosis in Zhijin County, Guizhou, China. Appl. Geochem. 22 1017-1024.

Dai, S., Ren, D., 2007. Effects of magmatic intrusion on mineralogy and geochemistry of coals from the Fengfeng-Handan Coalfield, Hebei, China. Energy Fuel 21, 1663-1673.

Dai, S., Ren, D., Tang, Y., Shao, L., Li, S., 2002. Distribution, isotopic variation and origin of sulfur in coals in the Wuda coalfield, Inner Mongolia, China. Int. J. Coal Geol. 51, 237-250.

Dai, S., Seredin, V.V., Ward, C.R., Jiang, J., Hower, J.C., Song, X., Jiang, Y., Wang, X., Gornostaeva, T., Li, X., Liu, H., Zhao, L., Zhao, C., 2014. Composition and modes of occurrence of minerals and elements in coal combustion products derived from highGe coals. Int. J. Coal Geol. 121, 79-97.

Dai, S., Wang, X., Seredin, V.V., Hower, J.C., Ward, C.R., O'Keefe, J.M., Huang, W., Li, T., Li, X. Liu, H., Xue, W., Zhao, L., 2012a. Petrology, mineralogy, and geochemistry of the Gerich coal from the Wulantuga Ge ore deposit, Inner Mongolia, China: new data and genetic implications. Int. J. Coal Geol. 90, 72-99.

Dai, S., Zeng, R., Sun, Y., 2006. Enrichment of arsenic, antimony, mercury, and thallium in a Late Permian anthracite from Xingren, Guizhou, Southwest China. Int. J. Coal Geol. 66, 217-226.

Dai, S., Zou, J., Jiang, Y., Ward, C.R., Wang, X., Li, T., Xue, W., Liu, S., Tian, H., Sun, X., Zhou, D., 2012b. Mineralogical and geochemical compositions of the Pennsylvanian coal in the Adaohai Mine, Daqingshan Coalfield, Inner Mongolia, China: modes of occurrence and origin of diaspore, gorceixite, and ammonian illite. Int. J. Coal Geol. 94, 250-270.

Diessel, C.F.K., 1992. Coal Formation and Sequence Stratigraphy. Springer, Berlin.

Dvořák, J., Honěk, J., Pešek, J., Valterová, P., 1997. Deep borehole evidence for a southward extension of the Early Namurian deposits near Němčičky, S. Moravia, Czech Republic: implication for rapid coalification. In: Gayer, R., Pešek, J. (Eds.), European Coal Geology and Technology. Geological Society of London Special Publications, London, pp. 179-193.

ECE-UN, 1998. International Classification of In-Seam Coals. United Nations Economic Commission for Europe, Geneva.

Ellis, D., Bell, B.R., Jolley, D.W., O'Callaghan, M., 2002. The stratigraphy, environment of eruption and age of the Faroes Lava Group, NE Atlantic Ocean. Geol. Soc. Lond. Spec. Publ. 197, 253-269.

Eskenazy, G.M., Valceva, S.P., 2003. Geochemistry of beryllium in the Mariza-east lignite deposit (Bulgaria). Int. J. Coal Geol. 55, 47-58.

Fein, J.B., Williams-Jones, A.E., 1997. The role of mercury-organic interactions in the hydrothermal transport of mercury. Econ. Geol. 92, 20-28.

Finkelman, R.B., Bostick, N.H., Dulong, F.T., Senftle, F.E., Thorpe, A.N., 1998. Influence of an igneous intrusion on the inorganic geochemistry of a bituminous coal from Pitkin County, Colorado. Int. J. Coal Geol. 36, 223-241.

Finkelman, R.B., Palmer, C.A., Krasnow, M.R., Aruscavage, P.J., Sellers, G.A., Dulong, F.T. 1990. Combustion and leaching behavior of elements in the Argonne premium coal samples. Energy Fuel 4, 755-766.

Galushkin, Y.I., 1997. Thermal effects of igneous intrusions on maturity of organic matter: a possible mechanism of intrusion. Org. Geochem. 26, 645-658.

Gamson, P., Beamish, B., Johnson, D., 1996. Coal microstructure and secondary mineralization: their effect on methane recovery. Geol. Soc. Lond. Spec. Publ. 109, 165-179.

Golab, A.N., Carr, P.F., 2004. Changes in geochemistry and mineralogy of thermally altered coal, Upper Hunter Valley, Australia. Int. J. Coal Geol. 57, 197-210.

Goodarzi, F., Cameron, A.R., 1990. Organic petrology and elemental distribution in thermally altered coals from Telkwa, British Columbia. Energy Sources 12, 315-343.

Gurba, L.W., Ward, C.R., 2000. Elemental composition of coal macerals in relation to vitrinite reflectance, Gunnedah Basin, Australia, as determined by electron microprobe analysis. Int. J. Coal Geol. 44, 127-147.

Gürdal, G., 2011. Abundances and modes of occurrence of trace elements in the Can coals (Miocene), Çanakkale-Turkey. Int. J. Coal Geol. 87, 157-173.

Gürdal, G., Bozcu, M., 2011. Petrographic characteristics and depositional environment of Miocene Çan coals, Çanakkale-Turkey. Int. J. Coal Geol. 85, 143-160.

Hughes, H.S. McDonald, I., Kerr, A.C., 2015. Platinum-group element signatures in the North Atlantic Igneous Province: implications for mantle controls on metal budgets during continental breakup. Lithos $233,89-110$

ICCP, 2001. The new inertinite classification (ICCP System 1994). Fuel 80, 459-471.

ISO 5069-1:1983, 1983. Brown Coals and Lignites - Principles of Sampling - Part 1: Sampling for Determination of Moisture Content and for General Analysis. Internationa Organization for Standardization, Geneva.

ISO 7404-3:2009, 2009. Methods for the Petrographic Analysis of Coals - Part 3: Method of Determining Maceral Group Composition. International Organization for Standardization, Geneva.

Jolley, D.W., Bell, B.R., 2002. The evolution of the North Atlantic Igneous Province and the opening of the NE Atlantic rift. In: Jolley, D.W., Bell, B.R. (Eds.), The North Atlantic Igneous Province: Stratigraphy, Tectonic, Volcanic and Magmatic Processes. Geologica Society of London Special Publications, London, pp. 1-13.

Ketris, M.P., Yudovich, Y.E., 2009. Estimations of Clarkes for Carbonaceous biolithes: world averages for trace element contents in black shales and coals. Int. J. Coal Geol. 78, 135-148.

Khorasani, G.K., Murchison, D.G., Raymond, A.C., 1990. Molecular disordering in natura cokes approaching dyke and sill contacts. Fuel 69, 1037-1046.

Kilgroe, J.D., Sedman, C.B., Srivastava, R.K., Ryan, J.V., Lee, C.W., Thorneloe, S.A., 2002. Contro of Mercury Emissions from Coal-fired Electric Utility Boilers: Interim Report. Air Pollution Prevention and Control Division. U.S. Environmental Protection Agency, Durham.

Kisch, H.J., Taylor, G.H., 1966. Metamorphism and alteration near an intrusive-coal contact. Econ. Geol. 61, 343-361.

Kolcon, I., Sachsenhofer, R.F., 1999. Petrography, palynology and depositional environments of the early Miocene Oberdorf lignite seam (Styrian Basin, Austria). Int J. Coal Geol. 41, 275-308.

Kolker, A., Senior, C.L., Quick, J.C., 2006. Mercury in coal and the impact of coal quality on mercury emissions from combustion systems. Appl. Geochem. 21, 1821-1836.

Kuboušková, S., Krmíček, L., Pokorný, R., 2015. Coal deposits in the Faroe Islands. Geosci. Res. Rep. for 2014. ISBN: 978-80-7075-884-7, pp. 115-120 (in Czech with English abstract).
Kwiecińska, B., Petersen, H.I., 2004. Graphite, semi-graphite, natural coke, and natural char classification - ICCP system. Int. J. Coal Geol. 57, 99-116.

Laier, T., Nytoft, H.P., Jørgensen, O., Isaksen, G.H., 1997. Hydrocarbon traces in the Tertiary basalts of the Faeroe Islands. Mar. Pet. Geol. 14, 257-266.

Li, J., Zhuang, X., Querol, X., Font, O., Moreno, N., Zhou, J., Lei, G., 2012. High quality of Jurassic coals in the Southern and Eastern Junggar Coalfields, Xinjiang, NW China: geochemical and mineralogical characteristics. Int. J. Coal Geol. 99, 1-15.

Littke, R., Klussmann, U., Krooss, B., Leythaeuser, D., 1991. Quantification of loss of calcite, pyrite, and organic matter due to weathering of Toarcian black shales and effects on kerogen and bitumen characteristics. Geochim. Cosmochim. Acta 55, 3369-3378.

Liu, G., Zheng, L., Gao, L., Zhang, H., Peng, Z., 2005. The characterization of coal quality from the Jining coalfield. Energy 30, 1903-1914.

Lund, J., 1989. A late Paleocene non-marine microflora from the interbasaltic coals of the Faeroe Islands, North Atlantic. Bull. Geol. Soc. Den. 37, 181-203.

Markič, M., Sachsenhofer, R.F., 1997. Petrographic composition and depositional environments of the Pliocene Velenje lignite seam (Slovenia). Int. J. Coal Geol. 33, 229-254.

Mastalerz, M., Drobniak, A., Schimmelmann, A., 2009. Changes in optical properties, chemistry, and micropore and mesopore characteristics of bituminous coal at the contact with dikes in the Illinois Basin. Int. J. Coal Geol. 77, 310-319.

McDonough, W.F., Sun, S.S., 1995. The composition of the Earth. Chem. Geol. 120, 223-253.

Merritt, R.D., 1985. Review of coking phenomena in relation to an occurrence of prismatically fractured natural coke from the Castle Mountain mine, Matanuska coal field, Alaska. Int. J. Coal Geol. 4, 281-298.

Moiseyev, A.N., 1971. A non-magmatic source for mercury ore deposits? Econ. Geol. 66, 591-601.

Mukherjee, A.B., Zevenhoven, R., Bhattacharya, P., Sajwan, K.S., Kikuchi, R., 2008. Mercury flow via coal and coal utilization by-products: a global perspective. Resour. Conserv. Recycl. 52, 571-591.

Mukhopadhyay, P.K., 1989. Organic Petrography and Organic Geochemistry of Texas Tertiary Coals in Relation to Depositional Environment and Hydrocarbon Generation. Bureau of Economic Geology. University of Texas, Austin 978-9991387178.

Noe-Nygaard, A., Rasmussen, J., 1968. Petrology of a 3,000 metre sequence of basaltic lavas in the Faeroe Islands. Lithos 1, 286-304.

Øster-Mortensen, J., 2002. De sidste kulminearbejdere. Ilustrated 2, 34-37.

Parra, M., Delmont, P., Dumon, J.C., Ferragne, A., Pons, J.C., 1987. Mineralogy and origin of Tertiary interbasaltic clays from the Faeroe Islands, northeastern Atlantic. Clay Miner. $22,63-82$

Passey, S.R., 2014. The habit and origin of siderite spherules in the Eocene coal-bearing Prestfjall Formation, Faroe Islands. Int. J. Coal Geol. 122, 76-90.

Passey, S.R., Jolley, D.W., 2009. A revised lithostratigraphic nomenclature for the Palaeogene Faroe Islands Basalt group, NE Atlantic Ocean. Earth Env. Sci. T. R. So. 99, 127-158

Passey, S.R., Varming, T., 2010. Surface interpolation within a continental flood basalt province: an example from the Palaeogene Faroe Islands Basalt Group. J. Struct. Geol. 32, 709-723.

Peabody, C.E., Einaudi, M.T., 1992. Origin of petroleum and mercury in the Culver-Baer cinnabar deposit, Mayacmas district, California. Econ. Geol. 87, 1078-1103.

Poissant, L., Zhang, H.H., Canário, J., Constant, P., 2008. Critical review of mercury fates and contamination in the arctic tundra ecosystem. Sci. Total Environ. 400, $173-211$.

Pokorný, R., Krmíček, L., Árting, U.E., 2015. The first evidence of trace fossils and pseudofossils in the continental interlava volcaniclastic sediments on the Faroe Islands. Bull. Geol. Soc. Den. 63, 45-57.

Querol, X., Turiel, J.F., Soler, A.L., Duran, M.E., 1992. Trace elements in high-S subbituminous coals from the Teruel Mining District, northeast Spain. Appl. Geochem. 7, 547-561

Rahman, M.W., Rimmer, S.M., 2014. Effects of rapid thermal alteration on coal: geochemical and petrographic signatures in the Springfield (No. 5) Coal, Illinois Basin. Int. J. Coal Geol. 131, 214-226.

Rasmussen, J., Noe-Nygaard, A., 1969. Beskrivelse til geologisk kort over Færøerne. C. A. Reitzels Forlag, København (in Danish)

Rasmussen, J., Noe-Nygaard, A., 1970. Geology of the Faeroe Islands (Pre-quaternary). C. A. Reitzels Forlag, København.

Richardson, K.R., Smallwood, J.R., White, R.S., Snyder, D.B., Maguire, P.K.H., 1998. Crustal structure beneath the Faroe Islands and the Faroe-Iceland ridge. Tectonophysics 300, 159-180.

Rudnick, R.L., Gao, S., 2014. Composition of the continental crust. In: Holland, H., Turekian, K. (Eds.), Treatise on Geochemistry 4, second ed. Elsevier, Amsterdam, pp. 1-51.

Saunders, A.D., Fitton, J.G., Kerr, A.C., Norry, M.J., Kent, R.W., 1997. The North Atlantic Igneous Province. In: Mahoney, J.J., Coffin, M.F. (Eds.), Large Igneous Provinces: Continental, Oceanic, and Planetary Flood Volcanism. American Geophysical Union, Washington D. C, pp. 45-93.

Schobert, H., 2013. Chemistry of Fossil Fuels and Biofuels. Cambridge University Press, Cambridge.

Scott, A.C., 2002. Coal petrology and the origin of coal macerals: a way ahead? Int. J. Coal Geol. 50, 119-134.

Shotyk, W., Goodsite, M.E., Roos-Barraclough, F., Givelet, N., Le Roux, G., Weiss, D., Cheburkin, A.K., Knudsen, K., Heinemeier, J., van Der Knaap, W.O., Norton, S.A., Lohse, C., 2005. Accumulation rates and predominant atmospheric sources of natural and anthropogenic $\mathrm{Hg}$ and $\mathrm{Pb}$ on the Faroe Islands. Geochim. Cosmochim. Acta 69, $1-17$.

Singh, A.K., Sharma, M., Singh, M.P., 2008. Genesis of natural cokes: some Indian examples. Int. J. Coal Geol. 75, 40-48.

Singh, A.K., Singh, M.P., Sharma, M., Srivastava, S.K., 2007. Microstructures and microtextures of natural cokes: a case study of heat-affected coking coals from the Jharia coalfield, India. Int. J. Coal Geol. 71, 153-175.

Singh, P.K., Singh, M.P., Singh, A.K., Arora, M., 2010. Petrographic characteristics of coal from the Lati Formation, Tarakan basin, East Kalimantan, Indonesia. Int. J. Coal Geol. $81,109-116$. 
Smellie, J.L., Johnson, J.S., McIntosh, W.C., Esser, R., Gudmundsson, M.T., Hambrey, M.J., De Vries, B.V.W., 2008. Six million years of glacial history recorded in volcanic lithofacies of the James Ross Island Volcanic Group, Antarctic Peninsula. Palaeogeogr. Palaeoclimatol. Palaeoecol. 260, 122-148.

Stokes, A.H., 1874. Notes on the coal seam and geology on Suderøe. Trans. Chester. Derby. Inst. Min. Engrs. 11, 320-341.

Storey, M., Duncan, R.A., Tegner, C., 2007. Timing and duration of volcanism in the North Atlantic Igneous Province: implications for geodynamics and links to the Iceland hotspot. Chem. Geol. 241, 264-281.

Strobl, S.A., Sachsenhofer, R.F., Bechtel, A., Meng, Q. 2014. Paleoenvironment of the Eocene coal seam in the Fushun Basin (NE China): implications from petrography and organic geochemistry. Int. J. Coal Geol. 134, 24-37.

Suchý, V., Sýkorová, I., Stejskal, M., Šafanda, J., Machovič, V., Novotná, M., 2002. Dispersed organic matter from Silurian shales of the Barrandian basin, Czech Republic: optical properties, chemical composition and thermal maturity. Int. J. Coal Geol. 53, 1-25.

Swaine, D.J., Goodarzi, F., 1995. Environmental Aspects of Trace Elements in Coal. Kluwer Academic Publishers, Amsterdam.

Taylor, G.H., Teichmüller, M., Davis, A., Diessel, C.F.K., Littke, R., Robert, P., 1998. Organic Petrology. Gebrüder Borntraeger, Berlin.

Teichmüller, M., 1989. The genesis of coal from the viewpoint of coal petrology. Int. J. Coal Geol. 12, 1-87.

Van Krevelen, D.W., 1963. Geochemistry of Coal. In: Breger, I.A. (Ed.), Organic Geochemistry. Pergamon Press, Oxford, pp. 183-247.

Waagstein, R., Guise, P., Rex, D., 2002. K/Ar and ${ }^{39} \mathrm{Ar} /{ }^{40} \mathrm{Ar}$ whole-rock dating of zeolite facies metamorphosed flood basalts: the upper Paleocene basalts of the Faroe Islands,
NE Atlantic. In: Jolley, D.W., Bell, B.R. (Eds.), The North Atlantic Igneous Province: Stratigraphy, Tectonic, Volcanic and Magmatic Processes. Geological Society of London Special Publications, London, pp. 219-252.

Wang, L., Cheng, L.B., Cheng, Y.P., Yin, G.Z., Cai, C.C., Xu, C., Jin, K., 2014. Thermal effects of magmatic sills on coal seam metamorphism and gas occurrence. Bull. Volcanol. 76, 1-16.

Ward, C.R., Warbrooke, P.R., Roberts, F.I., 1989. Geochemical and mineralogical changes in a coal seam due to contact metamorphism, Sydney Basin, New South Wales, Australia. Int. J. Coal Geol. 11, 105-125.

Whitney, D.L., Evans, B.W., 2010. Abbreviations for names of rock-forming minerals. Am. Mineral. 95, 185-187.

Wing, S.L., Hickey, L.J., 1984. The Platycarya perplex and the evolution of the Juglandaceae. Am. J. Bot. 71, 388-411.

Xu, W., Wang, H., Zhu, T., Kuang, J., Jing, P., 2013. Mercury removal from coal combustion flue gas by modified fly ash. J. Environ. Sci. 25, 393-398.

Yao, Y., Liu, D., 2012. Effects of igneous intrusions on coal petrology, pore-fracture and coalbed methane characteristics in Hongyang, Handan and Huaibei coalfields, North China. Int. J. Coal Geol. 96, 72-81.

Yudovich, Y.E., Ketris, M.P., 2005a. Mercury in coal: a review: Part 1. Geochemistry. Int J. Coal Geol. 62, 107-134.

Yudovich, Y.E., Ketris, M.P., 2005b. Mercury in coal: a review: Part 2. Coal use and environmental problems. Int. J. Coal Geol. 62, 135-165.

Zhang, J., Ren, D., Zhu, Y., Chou, C.L., Zeng, R., Zheng, B., 2004. Mineral matter and potentially hazardous trace elements in coals from Qianxi Fault Depression Area in southwestern Guizhou, China. Int. J. Coal Geol. 57, 49-61. 